\title{
Symposium review: Technologies for improving fiber utilization*
}

\author{
A. T. Adesogan, ${ }^{1}$ † K. G. Arriola, ${ }^{1}$ Y. Jiang, ${ }^{1}$ A. Oyebade, ${ }^{1}$ E. M. Paula, ${ }^{1}$ A. A. Pech-Cervantes, ${ }^{1}$ J. J. Romero, ${ }^{2}$ \\ L. F. Ferraretto, ${ }^{1}$ and D. Vyas ${ }^{1}$ \\ ${ }^{1}$ Department of Animal Sciences, Institute of Food and Agricultural Sciences, University of Florida, Gainesville 32611 \\ ${ }^{2}$ Animal and Veterinary Sciences Program, School of Food and Agriculture, University of Maine, Orono 04469
}

\section{ABSTRACT}

The forage lignocellulosic complex is one of the greatest limitations to utilization of the nutrients and energy in fiber. Consequently, several technologies have been developed to increase forage fiber utilization by dairy cows. Physical or mechanical processing techniques reduce forage particle size and gut fill and thereby increase intake. Such techniques increase the surface area for microbial colonization and may increase fiber utilization. Genetic technologies such as brown midrib mutants (BMR) with less lignin have been among the most repeatable and practical strategies to increase fiber utilization. Newer BMR corn hybrids are better yielding than the early hybrids and recent brachytic dwarf BMR sorghum hybrids avoid lodging problems of early hybrids. Several alkalis have been effective at increasing fiber digestibility. Among these, ammoniation has the added benefit of increasing the nitrogen concentration of the forage. However, few of these have been widely adopted due to the cost and the caustic nature of the chemicals. Urea treatment is more benign but requires sufficient urease and moisture for efficacy. Ammonia-fiber expansion technology uses high temperature, moisture, and pressure to degrade lignocellulose to a greater extent than ammoniation alone, but it occurs in reactors and is therefore not currently usable on farms. Biological technologies for increasing fiber utilization such as application of exogenous fibrolytic enzymes, live yeasts, and yeast culture have had equivocal effects on forage fiber digestion in individual studies, but recent meta-analyses indicate that their overall effects are positive. Nonhydrolytic expansinlike proteins act in synergy with fibrolytic enzymes to increase fiber digestion beyond that achieved by the enzyme alone due to their ability to expand cellulose microfibrils allowing greater enzyme penetration of the

Received July 5, 2018.

Accepted January 14, 2019.

*Presented as part of the Forages and Pastures Symposium: Fiber Digestibility - From Cell Wall Composition to Forage Utilization at the ADSA Annual Meeting, Knoxville, Tennessee, June 2018.

†Corresponding author: adesogan@ufl.edu cell wall matrix. White-rot fungi are perhaps the biological agents with the greatest potential for lignocellulose deconstruction, but they require aerobic conditions and several strains degrade easily digestible carbohydrates. Less ruminant nutrition research has been conducted on brown rot fungi that deconstruct lignocellulose by generating highly destructive hydroxyl radicals via the Fenton reaction. More research is needed to increase the repeatability, efficacy, cost effectiveness, and onfarm applicability of technologies for increasing fiber utilization.

Key words: fiber, digestion, technology, cow

\section{INTRODUCTION}

\section{Dietary Importance and Roles of Fiber}

Forages account for 40 to $100 \%$ of the ration of dairy cows (Peyraud et al., 1996; Bargo et al., 2002) and are vital for maintaining animal productivity and health. The higher fiber content of forages is the main nutritional factor that differentiates them from concentrates and results in a relatively lower energy value. Nevertheless, fiber plays a fundamentally important role in ruminant livestock production, health, and welfare. In addition to being an important energy source, it stimulates chewing and salivation, rumination, gut motility, and health, buffers ruminal acidosis, regulates feed intake, produces milk fat precursors, and is the structural basis of the scaffolding of the ruminal raft, which is vital for digestion of solid feed particles in the rumen. Cellulose and hemicellulose, the main components of fiber, are intrinsically ruminally digestible. However, their close association with lignin and hydroxycinnamic acids such as ferulic acid in the plant cell wall is the greatest hindrance to complete digestion of feeds, particularly forages and byproducts, and to utilization of the nutrients and energy they contain. The degree of association with lignin and hydroxycinnamic acids and various plant anatomical features differentiates digestible from indigestible fiber. This paper describes the strategic importance of increasing forage fiber utilization and then discusses the efficacy, mode of action, 
cost effectiveness, and benefits and disadvantages of different technologies for improving fiber digestion.

\section{Importance of Increasing Fiber Digestion}

It is critically important to increase fiber digestion for productivity, profitability, and environmental reasons. Incomplete fiber digestion reduces the profitability of dairy production by limiting intake and, hence, animal productivity, and increasing manure production. For instance, in corn cell walls, each percentage unit increase in lignin concentration, the main factor hindering cell wall digestion, decreased cell wall degradability by 2 percentage units (Grabber, 2005). A 1-unit increase in forage NDF digestibility (NDFD) is associated with 0.17 and $0.25 \mathrm{~kg} / \mathrm{d}$ increases in DMI and milk production, respectively (Oba and Allen, 1999). In addition, in perennial ryegrass (Lolium perenne), a 5 to $6 \%$ increase in digestibility was estimated to increase milk production by up to $27 \%$ (Smith et al., 1998). Consequently, each percentage unit increase in lignin concentration in forage cell walls severely constrains DMI and milk production.

A second reason to increase fiber digestion is to increase energy supply from fibrous feeds that are not consumed by humans. Grains are high in energy and various processes have been developed for increasing the efficiency of energy of extraction from such feeds for ruminants and nonruminants. However, the growing demand for grains due to competition with the nonruminant feed, biofuel, and human food sectors results in considerable price hikes and volatility. Fibrous feeds for ruminants are less subject to such competing demands, but their recalcitrant lignocellulose matrix reduces the availability of the energy they contain, necessitating effective strategies for increasing the rate and efficiency of utilization of forage fiber and the energy therein.

It is equally necessary to increase fiber digestion for environmental reasons. Compared with that from starch, ruminal fermentation of fiber-derived hexoses generates more hydrogen ions that reduce carbon dioxide to methane. Consequently, fibrous feed fermentation results in greater production of methane and less energy supply than concentrate feeds. In addition to being a significant drain on energy supply to the cow, enteric methane production is a significant contributor to greenhouse gas emissions. It is the main source of agriculture-related methane emissions, which has resulted in advocation of vegan diets for environmental reasons (Poore and Nemecek, 2018) and cessation of livestock production, despite the critical role livestock and livestock products play in human nutrition, income generation, and livelihoods (Smith et al., 2013; Verain et al., 2015) or the fact that because ruminants convert forages that humans cannot consume into high quality food protein, only $14 \%$ of feed DM ingested by livestock is edible to humans (Mottet et al., 2017). Consequently, it is of paramount importance to increase forage fiber digestion to enhance animal productivity and environmental stewardship of livestock farming.

\section{Factors Affecting Forage Fiber Utilization}

Various animal, plant, and environmental factors that modulate the intake and digestibility of forage fiber have been described in excellent reviews (Galyean and Goetsch, 1993; Fales and Fritz, 2007). The main plant-based factors affecting the digestibility and intake of forage fiber will be summarized in this section. They include the following: (1) chemical composition of tissues in organs, (2) tissue type and proportion within organs, and (3) organ type and proportion in plants. The interplay between these factors has a major effect on the intake and digestion of nutrients by ruminants (Coleman et al., 2004; Jung, 2012), with chemical composition becoming more predominant than the other factors with increasing levels of mechanical processing (Pond et al., 1984; Wilson and Mertens, 1995). The main chemical and anatomical barriers limiting forage fiber utilization are described below.

Chemical Composition of Forage Cell Wall. Purified cellulose and xylan are rapidly digested in the rumen (Weimer et al., 1990; Colombatto et al., 2003). Likewise, the association between cellulose and xylan polymers mediated by intermolecular hydrogen bonds does not inhibit their degradation rates in ruminal fluid (Weimer et al., 2000). Lignin is the main barrier to fiber digestion (Van Soest, 1987) because it reduces the accessibility of enzymes to cellulose and xylan and reversibly or irreversibly adsorbs enzymes, resulting in lower rates of hydrolysis of structural polysaccharides (Bansal et al., 2009; Ju et al., 2013). Lignin cannot be decomposed under the anaerobic conditions of the rumen (Hatfield et al., 2007), and it compromises fiber digestibility through its interaction with cell wall carbohydrates (Hatfield et al., 1999a). The crosslinking of lignin to glucoronoarabinoxylans via ester and ether linkages with ferulates reduces the degradability of grass fiber (Jung and Phillips, 2010; Hatfield et al., 2017). Moreover, ferulate dimers, trimers, and tetramers crosslink glucoronoarabinoxylans (Hatfield et al., 1999b; Bunzel et al., 2005), and these ferulates can become linked to lignin (Hatfield et al., 2017), decreasing both the rate and the extent of cell wall degradation in grasses (Grabber et al., 1998). Casler and Jung (1999) reported higher levels of ferulate cross-linking at the same lignin concentration that decreased the NDFD of smooth bromegrass (Bromus inermis L.). The as- 
sociation of lignin and structural carbohydrates is accounted for in several nutritional models for cattle as "unavailable/undigested" NDF (NRC, 2001; Van Soest et al., 2005) and estimated using the ADL fraction or quantified as the proportion of NDF remaining after $240 \mathrm{~h}$ of in vitro or in situ ruminal incubation (Lopes et al., 2015; Van Amburgh et al., 2015).

Forage Tissue Type and Proportion. The different lignification patterns of plant tissues determine their digestibility (Akin, 1989; Jung, 2012), affecting chewing and rumination time (Coleman et al., 2004), particle size reduction (Wilson and Kennedy, 1996), ruminal rate of passage (Kennedy and Doyle, 1993), and ultimately animal performance (Batistoti et al., 2012). Tissues such as mesophyll, collenchyma, and phloem do not lignify and are highly digestible (Akin, 1989; Wilson, 1993). Conversely, lignified tissues such as the sclerenchyma, epidermis (not lignified in legumes), xylem, nonclorenchymatous parenchyma, and the parenchyma bundle sheath cells limit nutritive value and intake, with increasing recalcitrance as the plant matures, experience stresses, or both (Wilson, 1993; Rudall, 2007). The $\mathrm{C}_{4}$ grasses are typically less digestible than $\mathrm{C}_{3}$ grasses because they contain more of the lignified tissue types (Wilson, 1993). The middle lamella, the intercellular layer between walls of neighboring cells (Rudall, 2007), is one of the greatest constraints to fiber degradation by ruminant microbes (Coleman et al., 2004) because it is where lignin formation is initiated and most concentrated (Engels and Jung, 2005).

Forage Organ Type and Proportion. A high leaf to stem ratio is generally used as an indicator of greater nutritional value in forages (Balasko and Nelson, 2003). The differences in digestibility between leaves and stems arises from the distinct proportion of tissue types in each organ (Wilson, 1993; Wilson and Hatfield, 1997). Because leaves have high proportions of mesophyll cells, they are much more digestible than the lignified stem, which is high in nonchlorenchymatous parenchyma cells. Moreover, stems differ from leaf blades in that their tissue characteristics change greatly with maturity (Cherney and Marten, 1982), such that stem digestibility can be similar to or greater than that of leaves when young, but lower than that of leaves when mature (Hacker and Minson, 1981). This results from the lignification of key stem tissues, such as the nonchlorenchymatous parenchyma, which constitutes a powerful barrier to fiber digestion (Wilson, 1993).

At the primary cell wall development stage, when the first layers are formed, the cell wall is composed of cellulose, arabinoxylans, xyloglucans, mixed linkage glucans, pectin, and proteins (Vogel, 2008), as well as ferulic and $p$-coumaric acids in grasses (Jung and Casler, 1991). Lignin deposition is very limited during this initial phase (Evert, 2006). The secondary cell wall phase of development starts after the mature plant cell has reached its final size. Secondary cell walls are deposited inside the primary cell walls and can comprise at least $50 \%$ of the cell wall mass in both leaves and stems (Vogel, 2008). During this phase, lignin deposition starts in the middle lamella-primary wall region and then continues into the lumen side of the cell wall (Terashima and Fukushima, 1993). Consequently, the middle lamella-primary wall region is the most lignified and least digestible component (Jung and Allen, 1995).

\section{STRATEGIES TO INCREASE FORAGE FIBER DIGESTION}

The information presented below was based on studies retrieved from the literature with search key words that included the technology in question as well as the words "fiber, digestibility, milk production, DMI, and feed efficiency." Search engines used included Google Scholar (www.scholar.google.com), PubMed (www .www.ncbi.nlm.nih.gov/pubmed/), and Web of Science (www.webofknowledge.com). Preference was given to studies with in vivo rather than in vitro data.

\section{Mechanical Processing}

Mechanical processing is a crucial complementary step in forage production due to its effect on forage physical properties that cause gut fill and limit feed intake. Consequently, numerous studies have examined the influence of mechanical processing on particle size measures, typically the chop length of hay, straw, or silage or the particle size distribution of diets for lactating cows. Forage particle size is critically important in dairy cattle diets, which must contain sufficient physically effective NDF (Hall and Mertens, 2017), a combination of both physical (i.e., particle size) and chemical (i.e., NDF concentration) fiber characteristics (Mertens, 1997), to stimulate chewing and salivation and reduce gut fill, without reducing digestibility. In this context, grinding of forages or byproducts will not be discussed because it removes the physical effectiveness of fiber.

Chopping. Despite the undeniable benefits of coarser forage particles on ruminal mat formation, chewing activity, digestion, and milk fat content (Allen, 1997; Mertens, 1997), long forage particles may limit intake through reduced ruminal passage rate and increased fill (Mertens, 1987), promote dietary sorting (Leonardi and Armentano, 2003), and enhance the time spent consuming a meal (Grant and Ferraretto, 2018). Although particle size can be manipulated to enhance fiber digestibility, research findings have been inconsis- 
tent and the outcome is not related to alterations in the chemical composition of forage fiber. A meta-analysis of published studies (Ferraretto and Shaver, 2012b; Table 1) reported that digestibility of dietary NDF, DMI, and milk production was not altered by chop length of corn silage. This should not be surprising as fiber digestion is influenced by many factors and the combination of the benefits of long or short forage particles may be countered by the disadvantages. For instance, short forage particles have greater surface area for bacterial attachment, which may enhance forage digestibility despite their faster passage rate (Johnson et al., 1999). In contrast, coarse particles are retained for longer periods in the rumen and require more chewing, leading to greater ruminal $\mathrm{pH}$ (Allen, 1997), which is conducive for cellulolytic bacteria and forage digestion in general.

Shredding. Shredding ensiled whole-plant corn at harvest is an effective method to alter the physical characteristics of the silage. A recently developed form of silage, called corn shredlage, is produced when corn forage is harvested with a self-propelled forage harvester fitted with cross-grooved crop-processing rolls set at approximately $20 \%$ greater roll speed differential and chopped at a greater theoretical length of cut (22 to $26 \mathrm{~mm}$ ) than the norm. Despite the longer chop length used, the shredding process causes greater damage to coarse stover particles and kernels than conventional harvesting. Compared with conventionally processed silage, yields of $3.5 \% \mathrm{FCM}$ and actual milk were increased by 1.0 and $1.5 \mathrm{~kg} /$ cow per day when whole-plant corn was harvested as corn shredlage using either conventional (Ferraretto and Shaver, 2012a) or brown midrib (BMR; Vanderwerff et al., 2015) hybrids, respectively. These results were attributed to the greater kernel breakage obtained by shredding whole-plant corn and the corresponding improvements in ruminal in situ and total-tract in vivo starch digestibility (Ferraretto and Shaver, 2012a; Vanderwerff et al., 2015). Surprisingly, despite what appeared to be more thorough damage to the fibrous portion of the forage, Vanderwerff et al. (2015) reported that total-tract NDFD (TTNDFD) was 2 percentage units lower when cows were fed corn shredlage instead of conventionally processed corn silage. These authors associated this response with the negative effects of the greater digestibility of shredlage starch on TTNDFD. This premise was supported by the fact that ruminal in situ NDF (ISNDF) digestibility of undried and unground corn silage samples did not differ among treatments. Ferraretto and Shaver (2012a) also reported that ruminal ISNDF digestibility was unaffected when conventionally processed corn silage was compared with corn shredlage, though TTNDFD was not measured. Finally, near-infrared reflectance spectroscopy-predicted 30-h NDFD was lower in corn shredlage ( 55.0 vs. $53.4 \%$ of NDF) compared with conventionally processed corn silage in an assessment of 3,900 commercial samples (Ferraretto et al., 2018). Further research to understand the ruminal in vivo NDF digestion kinetics of corn shredlage is warranted. Although the benefits of harvesting corn silage with a shredlage processor are undeniable, some factors must be considered when evaluating the cost effectiveness. In addition to the costs associated with acquiring the processor (or a new self-propelled forage harvester), other factors such as changes in fuel usage and roll wear must be taken into consideration as they may differ from that involved in conventional processing. To our knowledge, this information is unavailable in the literature and should be the focus of future research.

Pelleting. Another potential alternative method to manipulate forage physical properties, and thereby fiber digestibility, is forage pelleting. In addition to the aforementioned effects of particle size, pelleting may enhance handling, storage, and transportation (Bonfante et al., 2016), and it enhances the use of certain bulky forage or crop residues as livestock feeds (Mani et al., 2006). The use of forage pellets, however, is not a new concept. For example, Clifton et al. (1967) evaluated coastal bermudagrass [Cynodon dactylon (L.) Pers.] fed as either silage or pellets. Cows fed forage pellets had greater intake but did not have greater animal performance. Caution is needed when forages are fed as pellets to due to the risk of acidosis from the reduced saliva production and resulting reduction in ruminal acid buffering caused by pelleting, but the effect may depend on the production stage of the cows. Bonfante et al. (2016) fed a pelleted TMR to growing heifers and did not observe adverse effects on rumen health, though the authors advocated examining the pellets for longer feeding periods. Total-tract digestibility of the potentially digestible NDF fraction was reduced, presumably due to reduced ruminal retention time. This suggests that using pelleted TMR for growing heifers may not adversely affect rumen health, but caution is needed to ensure digestibility is not reduced. In contrast, when alfalfa (Medicago sativa L.) pellets were substituted for alfalfa hay to induce SARA in dairy cows (Khafipour et al., 2009; 8 percentage-unit increments of alfalfa pellets from 0 to $40 \%$, DM basis) over $6 \mathrm{wk}$ without altering forage to concentrate ratio and starch concentration, a gradual increase in consumption of pellets instead of hay was evident but yields of milk and milk fat and ruminal $\mathrm{pH}$ decreased in a linear manner. The latter results emphasize that pelleting TMR for lactating cows can be detrimental and reinforces the need to account for physically effective NDF during diet formulation. Additional trials examining replacement of concentrates or mixtures of 
forages and concentrates with forage pellets are needed, particularly for heifers.

With the need to ensure the sustainability of feed production for the dairy industry (Martin et al., 2017), pelleting crop residues (i.e., corn stover, cereal straw) that are abundantly available may become an important practice (Mani et al., 2006), particularly as the need for cattle feeds that cannot be consumed by humans increases. Research to determine the best conditions for feeding forage pellets as well as the associated logistics and costs is warranted.

Steam Treatment. Steam heating or steam pressure and explosion have been used to pretreat forages to increase fiber digestibility. Steam heating of alfalfa hay was detrimental in the study by Broderick et al. (1993) as it reduced the rate of degradation and ruminal protein degradability. Such methods may be more useful for crop residues with their intrinsically low digestibility and protein concentrations. Steam pressure and explosion increased energy availability from rice straw, sugarcane bagasse, and sugarcane field trash by hydrolyzing cellulose and hemicellulose or by eliminating the crosslinks between these digestible fractions and lignin (Hart et al., 1980). Liu et al. (1999) reported also that steam treatment increased gas production and rate of gas production from rice straw. In a follow-up study, Liu and Orskov (2000) reported that cellulase treatment hydrolyzed the cellulose fraction of steamtreated rice straw but had only minor effects on the untreated straw. Zhao et al. (2018) reported that steam explosion increased ISNDFD of corn stover and led to greater separation of fiber components and increased the surface area for microbial attachment. In addition, lambs fed steam-treated corn stover had greater intake, presumably driven by greater cellulose digestibility (Oji and Mowat, 1978).

Overall, the use of pelleting or steam treatments offers new opportunities to enhance the nutritive value of forages and feedstuffs. However, the literature suggests that the benefits of such technologies are more prominent in crop residues than in higher quality forages. Research is needed on the cost effectiveness of such treatments.

Cutting Time. Previous studies have shown that cutting grasses or legumes in the afternoon (at sundown) increased the concentration of water-soluble carbohydrates (WSC; Lechtenberg et al., 1971; Fisher et al., 2002; Burns et al., 2005; Brito et al., 2008) due to accumulation of carbohydrates during the photoperiod, compared with cutting in the morning (at sunup). The increase in WSC concentration in the forage may improve DMI (Miller et al., 2001; Brito et al., 2008; Yari et al., 2014). For example, Burns et al. (2005) evaluated the effects of cutting time on alfalfa hay in goat, sheep, and cattle diets. Greater DMI was reported at sundown compared with sunup (2.97 vs. $2.83 \mathrm{~kg} / 100 \mathrm{~kg}$ of BW) in goats but not in sheep or cattle. However, apparent TTNDFD was not affected by cutting time in any species. Brito et al. (2008) evaluated the effect of cutting time at harvest of alfalfa baleage. Cutting alfalfa at sundown increased DMI (19.9 vs. $19.0 \mathrm{~kg} / \mathrm{d})$, milk yield (20.1 vs. $19.2 \mathrm{~kg} / \mathrm{d})$, and milk fat yield (0.82 vs. $0.75 \mathrm{~kg} / \mathrm{d}$ ) compared with cutting at sunup, but cutting time did not alter apparent TTNDFD (47.3 vs. $48.0 \%$ of NDF intake). The increase in milk production was attributed to the greater DM and OM digestibility, and microbial protein synthesis (Brito et al., 2008, 2009) of the alfalfa harvested at sundown. Pelletier et al. (2010) examined the nutritive value of 6 grasses and 2 legumes cut at 0900 and 1530 h. Nonstructural carbohydrate concentration was greater for all grasses and legumes cut at the afternoon, but ruminal in vitro NDFD (IVNDFD) was not affected by cutting time. Therefore, the literature suggests that harvesting at sundown rather than sunup increases forage WSC concentration and may increase DMI, microbial protein synthesis, and milk production by dairy cows. However, these improvements do not seem to be due to changes in fiber digestibility.

\section{Genetic Improvement}

Brown-Midrib Mutants. Improvements to fiber digestibility of forages are often accomplished by reducing lignin or indigestible NDF concentrations (Grant and Ferraretto, 2018). A viable approach to achieve such objectives is through genetic control of the lignification process or selection for naturally occurring mutations (Porter et al., 1978). For example, BMR mutant forages (e.g., corn, sorghum, and pearl millet) consistently have lower lignin concentrations compared with conventional forages (Sattler et al., 2010), which has resulted in greater milk production when the BMR forages are fed. In this context, BMR corn silage (BMRCS) has become a well-established alternative to conventional corn silage (CCS) in the United States. Several studies have reported greater DMI, passage rate, and rate of NDF digestion in cows fed BMRCS compared with CCS (Oba and Allen, 2000; Ebling and Kung, 2004). In a meta-analysis of published studies, Ferraretto and Shaver (2015) reported increases in TTNDFD (44.8 vs. $42.3 \%$ of intake), DMI (24.9 vs. $24.0 \mathrm{~kg} / \mathrm{d})$, yields of milk (38.7 vs. $37.2 \mathrm{~kg} / \mathrm{d})$, and protein (1.18 vs. 1.13 ) for cows fed BMRCS diets instead of CCS diets (Table 1). These benefits are associated with lower rumen gut fill as conventional forage-based diets may have lower rates of passage and digestion, causing physical constraints in the rumen (Allen, 1996) that limit intake. 
This concept is of particular interest when cows are in early lactation, when feed intake is limited (Dado and Allen, 1995). Consequently, feeding BMR forages is an effective strategy to increase NDFD and thereby mitigate the low intake of dairy cows in the periparturient period. In a study by Stone et al. (2012), cows fed BMRCS pre- and postpartum (14 d before to $21 \mathrm{~d}$ after calving) had greater DMI before and after calving (14.3 vs. $13.2 \mathrm{~kg} / \mathrm{d}$ and 20.1 vs. $18.1 \mathrm{~kg} / \mathrm{d}$, respectively), and greater milk yield ( 37.5 vs. $34.3 \mathrm{~kg} / \mathrm{d}$ ) than cows fed CCS. Furthermore, a carryover effect was observed. Cows fed BMRCS during the transition period had greater yields of protein, lactose, and solids from wk 4 to 15 (when cows were fed the same basal diet). Holt et al. (2013) evaluated the long-term effects of feeding BMRCS on DMI and performance of high-producing dairy cows from parturition to 180 DIM. Although DMI was similar from 1 to 60 DIM, a tendency to increase DMI was observed post-peak lactation when BMRCS was fed. In addition, cows fed BMRCS had greater milk yield post-peak (61 to 180 DIM) compared with their cohorts fed CCS (41.0 vs. $38.8 \mathrm{~kg} / \mathrm{d}$ ).

As for corn, BMR sorghum (Sorghum bicolor) has lower lignin concentration and greater fiber digestibility compared with conventional sorghum (Sattler et al., 2010). Aydin et al. (1999) compared conventional to BMR forage sorghum silage (BMRSS) in diets for dairy cows and reported greater in situ extent of ruminal fiber digestion, TTNDFD, and milk yield for the BMRSS. A follow-up study from the same group (Oliver et al., 2004) compared 2 BMR forage sorghum (bmr6 and bmr18) hybrids to conventional sorghum and CCS. Milk yield was greatest for BMRSS (bmr6) and CCS, intermediate for $(b m r 18)$, and least for conventional sorghum silage $(34.1,33.8,32.2$, and $31.0 \mathrm{~kg} / \mathrm{d}$, respectively). These results were attributable at least partly to the fact that TTNDFD was greatest for BMRSS (bmr6) and CCS, intermediate for BMRSS (bmr18), and least for conventional sorghum silage $(54.4,54.1$, 47.9 , and $40.8 \%$ of intake, respectively). Dann et al. (2008) compared BMR sorghum-sudangrass hybrid with CCS at 2 inclusion levels (35 or 45\%, DM basis) in the diet of lactating cows. Cows fed CCS had the greatest DMI regardless of the inclusion level, whereas DMI was intermediate for BMRSS at 35\% DM, and least for BMRSS at $45 \%$ DM. Despite the greater DMI for CCS diets, no difference in 3.5\% FCM was reported. The BMR sorghum sudangrass had greater fiber digestibility than its conventional counterpart and 10 percentage units greater 30 - and 48-h IVNDFD than the CCS, but no differences were observed among diets for TTNDFD. Bernard and Tao (2015) replaced 38.7\% of CCS in a TMR with brachytic dwarf BMRSS and dairy cow performance was not altered. These stud- ies indicate that BMRSS or sorghum sudangrass are superior in quality to the conventional alternatives and may be a viable alternative that stimulates as much milk production as CCS. Such BMR hybrids would be particularly desirable in areas or situations unsuitable for corn production. It is important to highlight, however, that despite the promising results observed when comparing BMR sorghum with conventional sorghum and corn, most of the studies were short-term studies (e.g., Latin square design with 21- or 28-d periods) and therefore long-term lactation studies are warranted. It is also pertinent to note that some studies have shown that lodging can be a problem for some BMR sorghum hybrids particularly when sown at high seeding rates (Pedersen et al., 2005), but the incidence may be reduced by increasing plant spacing or planting brachytic dwarf hybrids that are less prone to lodging (Bernard and Tao, 2015).

Another viable alternative forage to corn in lactation diets is pearl millet, particularly in areas where corn does not grow well. Pearl millet (Pennisetum glaucum) is a warm season annual grass that is adapted to low fertility soils and low $\mathrm{pH}$ soils and is resistant to heat and drought (Kumar and Adrews, 1993). Mustafa et al. (2004) reported lower ADL concentration (1.4 vs. 2.0\% of DM) and hence greater ISNDFD for forage BMR millet compared with conventional millet (34.6 vs. $27.3 \%$ of NDF). Recently, Harper et al. (2018) examined effects of partial replacement (20\%, DM basis) of corn silage with BMR dwarf pearl millet (BMRPM) in the diet of lactating dairy cows. The control diet contained corn silage and alfalfa haylage as the forage sources and both diets had a 60:40 forage to concentrate ratio. Cows fed the control diet had greater milk production (51.3 vs. $49.6 \mathrm{~kg} / \mathrm{d}$ ), but similar DMI and ECM yield compared with the BMRPM diet. Interestingly, ISNDFD was greater for BMRPM (37.3\% of NDF), intermediate for alfalfa haylage (27\%), and lowest for corn silage (21.9\%; Harper et al., 2018). However, the BMRPM was cut at an early stage, resulting in lower starch concentrations (24.1\%) than the corn silage (28\%), which may explain why feeding the BMRPM did not result in greater milk yield.

Genetic improvement is resulting in BMR hybrids that are higher yielding than earlier hybrids. Nevertheless, it is important to account for lower yields of certain BMR hybrids than conventional hybrids when deciding which hybrid to grow. Such lower yields may be outweighed by the improved animal performance from BMR hybrids (Table 1), but the magnitude of the improvements may vary from farm to farm based on the prevailing conditions. The difference in the cost of production per hectare of BMR versus conventional hybrids (Table 2) should also be taken into account. Pro- 
Table 2. Notional cost of technologies to improve fiber utilization

\begin{tabular}{|c|c|c|}
\hline Treatment & $\operatorname{Cost}^{1}$ & Cost $^{2}$ \\
\hline \multicolumn{3}{|l|}{ Mechanical processing $^{3}$} \\
\hline Chopping & & $\$ 6-10 / \mathrm{t}^{4}$ \\
\hline Shredding & $\mathrm{NA}^{5}$ & \\
\hline Steam treatment & NA & \\
\hline \multicolumn{3}{|l|}{ Genetic improvement } \\
\hline Non-brown midrib (BMR; non-bm3) corn hybrids & $\$ 247 /$ ha & $\$ 15.4-20.5 / \mathrm{t}^{6}$ \\
\hline Reduced-lignin alfalfa & $\$ 237.0 /$ ha & $\$ 10.5-15.8 / \mathrm{t}$ \\
\hline Conventional alfalfa & $\$ 123.6 /$ ha & $\$ 5.5-8.3 / \mathrm{t}$ \\
\hline Transgenic enzyme producing plants & NA & \\
\hline \multicolumn{3}{|l|}{ Alkali treatment } \\
\hline Liquid or anhydrous ammonia & & $\$ 30-40 / \mathrm{t}$ of forage \\
\hline Urea & & $\$ 15-20 / \mathrm{t}$ of forage \\
\hline \multicolumn{3}{|l|}{ Acid treatment } \\
\hline $\mathrm{H}_{2} \mathrm{SO}_{4}$ & & $\$ 20-30 / \mathrm{t}$ of forage \\
\hline Formic acid (sodium formate) & & $\$ 15-20 / \mathrm{t}$ of forage \\
\hline \multicolumn{3}{|l|}{ Biological treatment } \\
\hline Cellulase-xylanase and other enzymes & $\$ 8.80-10.0 / \mathrm{t}$ of TMR & \\
\hline Bacterial inoculants & & $\$ 0.88-1.1 / \mathrm{t}$ of forage \\
\hline Expansins & NA & \\
\hline Yeast and yeast products & $\$ 0.05-0.06 /$ head per $\mathrm{d}$ & \\
\hline \multicolumn{3}{|l|}{ White-rot fungi ${ }^{7^{*}}$} \\
\hline \multicolumn{3}{|c|}{ Brown-rot fungi ${ }^{7}$} \\
\hline \multicolumn{3}{|c|}{$\begin{array}{l}{ }^{1} \text { These cost estimates should be used with caution as they were obtained from industry representatives in an uncomprehensive survey. Actual } \\
\text { costs could vary with various factors including the company source, hauling distance, prevailing regulatory stipulations, discounts to loyal pro- } \\
\text { ducers, and so on. }\end{array}$} \\
\hline \multicolumn{3}{|c|}{${ }^{2}$ Cost on a metric tonne basis. } \\
\hline
\end{tabular}

ducers should consider establishing guidelines for using BMR hybrids such as feeding them to high-producing cows in early lactation while feeding less digestible conventional hybrids to cows in mid to late lactation. Such guidelines should be based on recommendations of animal nutritionists and agronomists who are familiar with the prevailing conditions on the dairy farm.

Ferulate Ester Mutation. Corn hybrids with seedling-leaf-ferulate-ester mutation (SFE) can have greater NDFD than the wild type. Jung and Phillips (2010) reported that corn hybrids with SFE had reduced formation of ferulate ether cross-links and thus greater in vitro cell wall digestibility. Furthermore, Jung et al. (2011) reported that feeding cows SFE-corn silage instead of isogenic CCS increased DMI and milk and $3.5 \%$ FCM yields (Table 1). More studies on SFE mutants are needed to enable proper utilization of this natural mutation.
Reduced-Lignin Alfalfa, Grasses, and Corn. Feeding reduced-lignin alfalfa to dairy cows has been studied for over a decade. Guo et al. (2001) examined the lignin concentration and IVNDFD of 6 independent transgenic alfalfa lines with reduced lignin concentration compared with control lines (nontransgenic) and reported a range from 13 to $29 \%$ in lignin concentration. Furthermore, they observed an increase of $8 \%$ IVNDFD for one of these transgenic lines compared with its isogenic counterpart. Mertens and McCaslin (2008) fed transgenic alfalfa hay with reduced lignin concentration ( 5.3 vs. $5.8 \%$ of $\mathrm{DM}$ ) to young lambs and observed greater NDF intake (1.6 vs. $1.42 \%$ of $\mathrm{BW} / \mathrm{d}$ ) and digestibility (57.5 vs. $49.1 \%$ of NDF intake) compared with a nontransgenic line. When this same transgenic alfalfa variety was fed to dairy cows by Weakley et al. (2008), TTNDFD was greater for cows fed transgenic compared with nontransgenic al- 
falfa, but no differences in DMI, milk yield, or milk fat concentration were observed. Li et al. (2015) tested effects of 2 transgenic alfalfa cultivars (Roundup-ready vs. Roundup-ready low-lignin) and reported greater in vitro TTNDFD for the low-lignin alfalfa. This response was primarily driven by alterations in the NDF to lignin ratio as lower NDF (30.1 vs. $31.6 \%$ of DM), but similar lignin ( 5.6 vs. $5.5 \%$ of DM) concentrations were reported for the Roundup-ready versus Roundup-ready low-lignin cultivar.

Fiber in $\mathrm{C}_{4}$ grasses is usually poorly digestible, less so than in $\mathrm{C}_{3}$ grasses, due to lignification of the thick-walled parenchyma-bundle sheath cells around the vascular bundles of the $\mathrm{C}_{4}$ grasses (Giordano et al., 2014). Consequently, transgenic reduced-lignin $\mathrm{C}_{4}$ grasses have been developed. For instance, Giordano et al. (2014) developed transgenic Paspalum dilatatum (dallisgrass) with reduced expression of cinnamoyl-CoA reductase, which catalyzes conversion of cinnamoyl CoA to cinnemaldehyde in the monolignol biosynthetic pathway and is considered to be the first step in the lignin-specific branch of the phenylpropanoid pathway. Relative to the wild type, up to a $20 \%$ reduction in total lignin concentration and a $37 \%$ decrease in guiacyl lignin in the leaf blade were reported as well as an increase in near-infrared reflectance spectroscopypredicted digestibility. Similar results were also observed in a transgenic corn mutant in which cell wall digestibility improved by 24 to $28 \%$ with only a $10 \%$ reduction in lignin content (Tamasloukht et al., 2011). However, no peer-reviewed dairy cow feeding studies on low-lignin alfalfa or other transgenic forages were found, so caution is required when interpreting these results; further studies evaluating responses of dairy cows are warranted.

The development of reduced-lignin varieties is of great interest to the dairy industry. As for BMR hybrids, it is important to account for potential variations in yields and prices (Table 2) when choosing between reduced-lignin alfalfa and conventional varieties.

Transgenic Enzyme-Producing Plants. Transgenic manipulation of plants to express fibrolytic enzymes may decrease the cost of production of exogenous fibrolytic enzymes (EFE) and is also an efficient method to increase hydrolysis or saccharification of forage biomass (Ransom et al., 2007; Taylor et al., 2008; Furukawa et al., 2014). This technology has been researched for biofuel production primarily. For instance, transgenic corn plants with the ability to express endo$1,4-\beta$ glucanase produced more fermentable sugars for ethanol production than wild type plants (Furukawa et al., 2014). A key requirement for such transgenic plants is that the enzymes are expressed during or after, rather than before, senescence (Biswas et al., 2006; Brunecky et al., 2011; Furukawa et al., 2014). In recent research, transgenic rice with the ability to express exoglucanases with a senescence-inducible promoter was more efficient at increasing saccharification of rice straw (Furukawa et al., 2014). Additional requirements are stability of the enzyme as demonstrated for fungal and bacterial cellulases in transgenic sugar cane by Harrison et al. (2014) and that the expression does not modify plant morphology and structure as demonstrated in transgenic alfalfa by Ziegelhoffer et al. (1999). Brunecky et al. (2011) reported that when transgenic corn plants with the ability to express an endocellulase from $\mathrm{Ac}$ idothermus cellulolyticus were tested, expression of the enzyme during cell wall construction reduced the recalcitrance of the cell walls, increasing acid digestion and saccharification, but did not affect the plant morphology and growth compared with wild types. Research on transgenic fibrolytic enzyme-producing forages is needed to examine potential use of this technology for improving fiber digestion and milk production by dairy cows.

High-Sugar Forages (Water-Soluble Carbohydrates). Conventional breeding techniques were used to develop a perennial ryegrass (Lolium perenne L.) cultivar with greater WSC concentration than conventional types. Miller et al. (2001) examined the effects of substituting this high-WSC ryegrass cultivar for the conventional counterpart (cv. AberElan) with typical WSC concentration in the diet of dairy cows in late lactation. Cows fed the high-WSC ryegrass variety had greater milk production (15.3 vs. $12.6 \mathrm{~kg} / \mathrm{d}$ ) and total-tract NDF (70 vs. $63 \%$ of intake) and ADF (68 vs. $60 \%$ of intake) digestibilities compared with their cohorts fed the conventional cultivar (Miller et al., 2001). Further research should explore if such benefits will occur from other forage species with higher than normal WSC concentrations.

\section{Alkali Treatment}

Alkali treatments are effective at breaking hemicellulose-lignin and lignocellulose bonds, hydrolyzing uronic and acetic acid esters, and disrupting cellulose crystallinity by inducing cellulose swelling (Jung and Deetz, 1993). These processes increase cell wall degradability and enable ruminal microorganisms to attack the structural carbohydrates and increase degradation of hemicellulose and cellulose (Jung and Deetz, 1993; Sun et al., 1995). Additionally, alkali treatment has potential to degrade lignin, thereby increasing its water solubility and allowing it to be removed from the cell wall (Chesson, 1988). Various alkalis including ammonia, sodium hydroxide $(\mathrm{NaOH})$, calcium oxide $(\mathrm{CaO})$, and calcium hydroxide $\left[\mathrm{Ca}(\mathrm{OH})_{2}\right]$ have been used to 
increase fiber digestion and hence nutritive value of low quality forages, particularly crop residues (Singh and Klopfenstein, 1998).

Ammoniation. Ammoniation is one of the most studied chemical treatments for improving forage quality as it improves forage digestibility due to hydrolytic action of the alkali on linkages between lignin and structural polysaccharides (Dean et al., 2008). Ammoniation of low-quality forages such as bermudagrass hay (Dean et al., 2008; Krueger et al., 2008b), bahiagrass hay (Krueger et al., 2008a), and cereal straws including barley, wheat, and oat (Horton and Steacy, 1979) has resulted in improved intake and increased DM and NDFD, and N concentration, and improved milk production (Kendall et al., 2009); however, the results on lactation performance are not consistent (Brown et al., 1990). Ammoniation can involve application of liquid or anhydrous ammonia or result from application of urea, or use of the ammonia-fiber expansion (AFEX) technology. Though ammonia treatment improves the nutritive value of low-quality forages, feeding ammoniated forage may induce acute toxicity in ruminants because of potential deleterious effects on the central nervous system by causing crazy cow syndrome or bovine bonkers (Muller et al., 1998). This is because ammoniation of high-quality forages such as alfalfa and small grain hays predisposes animals to consumption of the toxic compound 4-metylimidazol, produced after interaction of ammonia with reducing sugars (Jung and Allen, 1995; Muller et al., 1998). Consequently, ammoniation of immature forages with high sugar concentrations is not recommended. Furthermore, ammoniation of forages containing more than $30 \%$ moisture may reduce intake because of the hydrophilic nature of the alkali, which results in retention of the pungent-smelling ammonia gas (Brown and Kunkle, 1992).

Although ammoniation is effective at improving fiber digestibility and increasing $\mathrm{N}$ concentration, it has not gained widespread commercial acceptance due to the high cost of ammoniation, the caustic effect of the alkali when inhaled or ingested excessively by humans and animals, its corrosive effects on equipment, and the requirement for specialized distribution and handling systems (Krueger, 2006).

Urea treatment is a safer and easier method of ammoniation that poses far less handling and safety risks (Sundstol and Coxworth, 1984). In addition, it is less expensive than ammonia (Table 2) and is easy to transport and store. However, the amount of urease activity and moisture content of forages determines the efficacy of urea treatment, as both are required for the formation of ammonia from urea.

Ammonia-Fiber Expansion. An alternative to direct ammoniation alone that combines chemical and physical treatments is AFEX. The method involves ammoniating low-quality forages at high temperature and pressure, with subsequent pressure release and ammonia removal (Campbell et al., 2013; Griffith et al., 2016 ) or recycling. Bals et al. (2010) observed 206\% greater NDFD with AFEX treatment of late harvest switch grass relative to the untreated forage versus $56 \%$ greater digestibility with traditional ammoniation. Similarly, AFEX treatment increased IVNDFD of corn stover and wheat straw by 19 to 20\% (Bals et al., 2010). Recently, Griffith et al. (2016) reported 35 and $27 \%$ greater in vitro dry matter digestibility (IVDMD) and IVNDFD due to AFEX treatment of barley straw. Feeding trials with lactating dairy cows using AFEX-treated rice straw have shown adequate intake and no adverse health effects with the treated material (Weimer et al., 2003; Blummel et al., 2014). Recently, Mor et al. (2018) reported improved nutrient digestibility (DM, OM, CP, NDF, and ADF) of AFEXtreated wheat straw for lactating buffalo and cattle, underscoring its commercial potential as an alternative to high-quality forages or grains. However, acetamide, a co-product of the AFEX treatment produced during cleavage of acetyl groups from hemicellulose (Weimer et al., 1986), is not volatile, rather it can remain with the treated biomass thereby increasing its $\mathrm{N}$ content (Bals et al., 2011). Acetamide has been classified as Group 2B possible human carcinogen by the International Agency for Research on Cancer (Vismeh et al., 2018) because of incidences of liver carcinoma during feeding trials in rats (Jackson and Dessau, 1961; Fleischman et al., 1980). Recent studies suggest that ruminal accumulation of acetamide from AFEX treatment is transient and certain ruminal bacteria can grow on the amide (Mor et al., 2019). Nevertheless, research on the effects and fate of residual acetamide in cattle fed AFEX-treated forages are needed to ensure that meat and milk are not contaminated. Recent animal trials have not reported adverse health effects (Blummel et al., 2014; Griffith et al., 2016; Mor et al., 2018). The main advantages of AFEX treatment over traditional ammoniation method include safety, as the pellets generated are benign, ease of transport due to density of the pellets, and recycling of the ammonia. However, unlike traditional ammoniation in stacks or bales, which is possible on farms, AFEX treatment occurs in reactors, which makes it difficult for on-farm application and avoidance of transport costs, which can be substantial.

Sodium Hydroxide Treatment. Sodium hydroxide is another chemical treatment for improving forage quality (Jackson, 1977; Wrathall et al., 1989). Sodium hydroxide treatment originally entailed soaking forage with dilute $\mathrm{NaOH}$ for several days followed by washing to remove unreacted alkali (Jackson, 1977). This was 
effective at improving in vitro $\mathrm{OM}$ digestibility of a low-quality forage like rye straw from 46 to $71 \%$ (Sundstol, 1988); however, concerns over environmental pollution with the wastewater contaminated with $\mathrm{NaOH}$ and loss of digestible DM due to rinsing of treated forages led to development of the modified dry treatment method. The dry method of $\mathrm{NaOH}$ treatment involves spraying dilute $\mathrm{NaOH}$ onto the forage without rinsing before feeding. Treating rice straw with $4 \% \mathrm{NaOH}$ improved net energy value and increased DMI, and growth performance in steers and feeder lambs (Garrett et al., 1974); however, beneficial effects were limited to diets containing $72 \%$ rice straw and not with those containing $36 \%$ rice straw. Similarly, $\mathrm{NaOH}$ treatment (4\% DM basis) of corn stalks in combination with $50 \%$ moisture from added water increased OM digestibility by $20 \%$ compared with untreated stalks (Klopfenstein et al., 1972). The main advantage of the dry method is that it is less labor intensive and issues with wastewater pollution are avoided. However, because excess $\mathrm{NaOH}$ is not rinsed off, the chances of toxicity are greater if the samples are not uniformly treated. Like ammonia, $\mathrm{NaOH}$ is caustic and hazardous; consequently, alternatives such as $\mathrm{Ca}(\mathrm{OH})_{2}$ or $\mathrm{KOH}$ are sometimes used to replace or dilute $\mathrm{NaOH}$.

Potassium or Calcium Oxide or Hydroxide Treatment. Alternatives to ammonia and $\mathrm{NaOH}$ are less hazardous alkaline substances such as $\mathrm{CaO}$ and $\mathrm{Ca}(\mathrm{OH})_{2}$; for instance, $\mathrm{Ca}(\mathrm{OH})_{2}$ is less caustic and easier to handle. Wanapat et al. (2009) observed greater DM digestibility (DMD) and 3.5\% FCM production by Holstein dairy cows fed rice straw treated with a combination of urea $(2.2 \%)$ and $\mathrm{Ca}(\mathrm{OH})_{2}(2.2 \%)$ instead of untreated rice straw. Similarly, treating African millet, Indian millet, and tobacco stalks with $10 \% \mathrm{Ca}(\mathrm{OH})_{2}$ approximately doubled the DMD (Gandi et al., 1997). Calcium oxide treatment is equally effective at improving the nutritive value of low-quality forages. Chaudhry (1998) treated wheat straw with $\mathrm{CaO}$ and reported greater digestibility of OM, NDF, and ADF. Similarly, Shreck et al. (2015) reported greater DMI, feed efficiency, and ADG in beef steers with diets containing $5 \% \mathrm{CaO}$ treated-corn stover or wheat straw compared with diets using the untreated forages. Cook et al. (2016b) fractionated corn plants at harvest (top and bottom fractions) and treated the lower plant fraction or the whole plant with $\mathrm{Ca}(\mathrm{OH})_{2}$. The alkali increased DMI and milk production by dairy cows when treated whole-plant or lower plant (fed with the untreated top portion) fractions were compared with the corresponding untreated fractions. Inclusion of up to $20 \%$ wheat straw treated with $3 \% \mathrm{NaOH}$ plus $3 \% \mathrm{Ca}(\mathrm{OH})_{2}$ in diets of lactating cows resulted in similar ruminal $\mathrm{pH}$, osmolality, straw NDFD, and milk production to those of cows fed diets that contained alfalfa haylage only as the basal forage (Haddad et al., 1998).

The cost and caustic nature of alkalis have prevented their widespread adoption. Also, concerns over environmental pollution from certain alkali treatments further dampens the prospects of using them to improve forage quality. Hence, it is paramount to find safe, costeffective, environmentally friendly alternatives.

\section{Acid Treatment}

The use of acid hydrolysis for the pretreatment of lignocellulosic materials is well established (Kumar and Wyman, 2009). The pretreatment process is effective at hydrolyzing hemicellulose, decreasing cellulose crystallinity, and increasing the porosity of treated biomass (Sun and Cheng, 2005). To foster ease of handling and cost effectiveness, dilute acid treatment is preferred. Torget et al. (1990) treated switchgrass with dilute sulfuric acid $\left(\mathrm{H}_{2} \mathrm{SO}_{4} ; 0.45-0.50 \%, \mathrm{vol} / \mathrm{vol}\right)$ and reported $95 \%$ xylan hydrolysis and concomitant improvement in cellulose digestibility. Similar results were observed with dilute $\mathrm{H}_{2} \mathrm{SO}_{4}$ pretreatment of corn cobs and corn stover (Torget et al., 1991). Acid hydrolysis can also improve subsequent enzyme-mediated increases in cell wall digestibility by increasing the pore size of the treated material as reported for corn stover (Ishizawa et al., 2007). Although acid pretreatment is effective at improving the nutritive value of low-quality feed, it is not widely used for livestock production because of the cost, health hazards, and corrosive nature of the acids.

Previous studies have reported use of both inorganic $\left(\mathrm{H}_{2} \mathrm{SO}_{4}\right)$ and organic acids (formic acid) as silage preservatives (O'Kiely et al., 1989; Kennedy, 1990; Henderson, 1993), which have increased fiber digestion in some instances. Sulfuric acid reduces the $\mathrm{pH}$ of forage, thereby inhibiting the activity of undesirable bacteria such as enterobacteria and clostridia, and stimulating lactic acid bacteria; however, the effects on animal performance are not promising (O'Kiely et al., 1989; Kennedy, 1990). Organic acids, in particular formic acid, induce antibacterial activity and restrict the activity of lactic acid-producing bacteria, thereby conserving WSC for animals (Bosch et al., 1988). Studies have reported decreased acetic acid, lactic acid, and ammonia- $\mathrm{N}$ concentrations along with greater sugar concentrations with formic acid-treated alfalfa (Nagel and Broderick, 1992) or ryegrass (Mayne, 1993), compared with the control silage. The effects of feeding formic acid-treated silage on animal performance are inconsistent. Although treated ryegrass silage induced greater DMI in sheep (Jacobs et al., 1991) and dairy cows (Mayne, 1993), no DMI response was observed when treated alfalfa silage was fed to dairy cows (Nagel 
and Broderick, 1992), but because of improved nutrient utilization, milk production was increased (Nagel and Broderick, 1992). However, Mayne (1993) reported no effects on milk production in cows fed formic acidtreated ryegrass silage. The use of acids as silage preservatives has declined due to their corrosive effects on machinery and potential health hazards for humans (Lorenzo and O'Kiely, 2008). Ammonium tetraformate is a buffered form of formic acid, which is less corrosive in nature and easier to handle. Broderick et al. (2007) fed ammonium tetraformate-treated alfalfa silage to lactating dairy cows and reported greater DMI and yields of milk, milk protein, and FCM, and greater Nefficiency compared with untreated alfalfa silage.

Low quality forages and crop residues do not provide enough nutrients for optimizing animal production primarily due to low CP levels, high fiber and lignin concentrations, and low digestibility. Studies cited above showed the efficacy of both acid and alkali treatments at improving NDFD and nutritive value of crop residues such as straw and poor-quality forages. However, they have been used to a lesser extent in high-producing dairy cow rations in the United States because of safety concerns and because relatively few studies validating their efficacy and cost effectiveness exist. The literature summary shows that feeding forages treated with alkali and acids can have variable effects on DMI and lactation performance. On average, liquid or anhydrous ammonia application improved DMI and milk yield by 0.92 and $0.15 \mathrm{~kg} / \mathrm{d}$; however, urea treatment improved DMI by $1.36 \mathrm{~kg} / \mathrm{d}$ and milk yield by $0.58 \mathrm{~kg} / \mathrm{d}$ (Table 1). Similarly, $\mathrm{Ca}(\mathrm{OH})_{2}$ increased both DMI $(0.21 \mathrm{~kg} / \mathrm{d})$ and milk yield $(2.0 \mathrm{~kg} / \mathrm{d}), \mathrm{NaOH}$ reduced DMI $(-0.66$ $\mathrm{kg} / \mathrm{d}$ ) and improved milk yield by $0.25 \mathrm{~kg} / \mathrm{d}$, whereas formic acid increased DMI by $0.34 \mathrm{~kg} / \mathrm{d}$ and milk yield by $0.93 \mathrm{~kg} / \mathrm{d}$. Several of the results in Table 1 should be interpreted with caution because they were not based on a meta-analysis and some estimates represent the few dairy cow studies examining treatment of forages with specific chemicals. The literature summary indicates that these technologies can be strategically used to improve dairy cow performance on farms. However, the adoption and widespread use of these technologies for increasing digestibility of fiber in crop residues or TMR has been limited by their relatively high prices, corrosiveness on equipment in certain cases, hazardous nature, and the attendant need for precautions to safeguard animal, human, and environmental health during and after the treatment process.

\section{Exogenous Fibrolytic Enzymes}

Cellulase-Xylanase Enzymes. Limited understanding of the composition and mode of action of EFE has restricted the development of effective EFE preparations that consistently improve fiber digestion and the performance of cattle (Beauchemin and Holtshausen, 2010; Adesogan et al., 2014). The effects of EFE on forage nutritive value are influenced by various factors including the dose, activity, and composition (Eun and Beauchemin, 2007), proteomic profile (Romero et al., 2015a), prevailing $\mathrm{pH}$ and temperature (Arriola et al., $2011 \mathrm{a})$, presence of metal ion cofactors $\left(\mathrm{Ca}^{2+}, \mathrm{Co}^{2+}\right.$, $\mathrm{Fe}^{2+}, \mathrm{Mg}^{2+}$, and $\mathrm{Mn}^{2+}$; Romero et al., 2015b), animal performance level (Schingoethe et al., 1999), and the dietary fraction to which the EFE is applied (Dean et al., 2013).

The effects of EFE in ruminant diets can be classified as pre-ingestive, ruminal, and postruminal (McAllister et al., 2001). When EFE are applied to fibrous substrates before feeding, fiber hydrolysis can be observed as partial solubilization of NDF and ADF and release of sugars and free or monomeric hydroxycinnamic acids (Krueger et al., 2008b; Romero et al., 2015c), which may contribute to improvements in in vitro fiber digestibility (Romero et al., 2015a) and microbial growth (Forsberg et al., 2000). Furthermore, pre-ingestive hydrolysis seems to cause structural changes ("digestive pits") that make the feed more amenable to further degradation, even when substrates were autoclaved and washed before treatment (Nsereko et al., 2000). Adding EFE to the diet increases the hydrolytic capacity of the rumen mainly due to increased bacterial attachment (Wang et al., 2001) and stimulation of rumen microbial populations (Nsereko et al., 2002). Giraldo et al. (2008) and Gado et al. (2009) showed that EFE application to sheep and dairy cow diets, respectively, increased microbial growth and production of microbial protein. Furthermore, Morgavi et al. (2000) showed that synergism between $\mathrm{EFE}$ and ruminal microbes enhanced ruminal cellulose, xylan, and corn silage digestion. Adding EFE may also increase the hydrolytic capacity of the rumen by adding complementary enzyme activities that are absent. Rumen metagenomic and metatranscriptomic studies have shown that the glycoside hydrolase family GH7 is absent in the rumen but is present in certain aerobic microorganisms (Dai et al., 2015). Badhan et al. (2014) reported that adding the recombinant enzyme EGL7A (endo- $\beta$-1,4-glucanase, GH7) from the aerobic fungi Thielavia terrestris to ruminal enzymes increased the digestion of alkaline peroxide-treated barley straw and alfalfa hay in vitro. Postruminal EFE effects seem to be limited to decreasing duodenal digesta viscosity and potentially increasing absorption of nutrients (McAllister et al., 2001). Decreased duodenal viscosity seems to be correlated with increasing xylanase activity in the duodenum when EFE are supplemented (Hristov et al., 1998, 2000), with xylanase activity surviving 
abomasal conditions to a greater extent than endoglucanase or amylase activity (Hristov et al., 1998, 2000).

Application of EFE often increases fiber hydrolysis and NDFD of forages, which partially explains their ability to improve animal performance. A recent metaanalysis of published studies reported that EFE application to dairy cow diets resulted in an increase in milk yield $(0.83 \mathrm{~kg} / \mathrm{d})$ and this was attributed to a tendency for EFE to improve NDFD and DMD (Arriola et al., 2017; Table 1). This meta-analysis also reported that application to the TMR instead of the concentrate or forage tended to improve milk protein concentration. Another recent meta-analysis reported an increase in milk yield $(1.9 \mathrm{~kg} / \mathrm{d})$ when cows were fed enzyme-treated diets containing high forage to concentrate ratios $(\geq 50 \%)$, but no increase occurred when diets with low forage to concentrate ratios $(<50 \%)$ were fed (Tirado-Gonzalez et al., 2018; Table 1). The latter study also reported that cellulase-xylanase enzyme treatment of high-forage legume-based diets increased milk production by cows $(2.3 \mathrm{~kg} / \mathrm{d})$ and xylanase treatment of high-forage grass-based diets improved milk yield $(3.1 \mathrm{~kg} / \mathrm{d})$.

Though the meta-analyses cited above indicate that overall effects of EFE on fiber digestion and milk yield by dairy cows are positive, the results of individual studies have been variable. This is partly because of inadequate understanding of enzyme nomenclature and activity, which results in some ineffective preparations (Adesogan et al., 2014), degradation of enzymes and loss of their activities in the rumen (Colombatto and Beauchemin, 2003; Arriola et al., 2017), adaptation of enzymes developed for paper, textile, and other applications for ruminant nutrition (Beauchemin et al., 2003; Adesogan et al., 2014), and formulation of enzyme products that do not complement ruminal enzyme activities (Ribeiro et al., 2018). Recent approaches such as proteomics, metagenomics, and metatranscriptomics are providing a better understanding of the structure, interaction, and functions of the ruminal microbial community (Meale et al., 2014) and the enzyme activities missing from the rumen that are critical for increased fiber digestion (Dai et al., 2015). The knowledge generated by these new techniques should be exploited in formulating enzyme preparations that will persist in the rumen and effectively and consistently improve fiber digestion.

Exogenous fibrolytic enzyme application can increase milk production by dairy cows (Table 1); however, the response can vary with enzyme type, application rate, lactation stage of the cows, study duration, experimental design, and so on. Therefore, despite the overall positive effect fibrolytic enzyme treatment on milk production across studies (Table 1), widespread adoption has been limited by the inconsistency in the response and the relatively high cost (Table 2).

Ferulic Acid Esterase. Ferulic and p-coumaric acid esterases have been used recently to increase the potency of EFE in ruminant diets (Beauchemin et al., 2003; Krueger et al., 2008a). When ferulic acid crosslinks arabinoxylans and lignin via ester and ether linkages, respectively, the extent of digestion is reduced dramatically (Jung and Deetz, 1993; Grabber et al., 1998). Jung and Allen (1995) hypothesized that the ester portion of the ferulic acid bridge is not available to enzymes because the lignin polymer is in such close proximity, impeding substrate attachment. This may partly explain the variable results observed when ferulic acid esterase (FAE) is applied to forages. Krueger et al. (2008a) reported that treatment with an EFE containing esterase activity from Humicola sp. increased the 24-h IVNDFD and release of ester-linked ferulic acid from Pensacola bahiagrass but not from Coastal or Tifton 85 bermudagrass. Interestingly, increased release of ether-linked ferulic acid from Tifton 85 bermudagrass also was reported. Etherase enzymes are required to hydrolyze ether linkages and release ether-linked ferulic acid from cell walls, but they are produced rarely by fungi and not present in the rumen environment. Mathieu et al. (2013) reported no $\beta$-etherase activity from 26 fungal strains (including Humicola grisea, Aspergillus sp., and Trichoderma viride) within 3 ecological groups (white-, brown-, and soft-rot fungi) cultured with Tien and Kirk medium and supplemented with or without sawdust. The authors concluded that cleavage of $\beta$-aryl ether linkage by extracellular $\beta$-etherase is a rare and nonessential activity among wood-decaying fungi.

\section{Bacterial Inoculant Treatment}

Applying EFE with microbial inoculants to forages at ensiling is beneficial as they may hydrolyze plant cell walls into sugars that serve as fermentation substrates, thus improving silage fermentation, nutrient preservation, and utilization of the silage by animals (Muck and Bolsen, 1991). Consequently, some silage inoculant preparations contain fibrolytic enzymes, mainly cellulases or xylanases, and some studies have reported increased NDFD due to application of such products (Filya and Sucu, 2010; Queiroz et al., 2012).

In addition, certain inoculants contain bacteria that secrete fibrolytic enzymes including cellulases and xylanases that may contribute to increased fiber digestion. However, except for FAE, the enzyme-secreting ability of inoculant bacteria is rarely declared, and in recent meta-analyses, although no effects on NDFD were observed when bacterial homofermentative and facultative heterofermentative inoculants were applied to 
forages, milk yield was improved (Oliveira et al., 2017; Table 1). More information is needed on the enzyme activities produced by inoculant bacteria, as this may lead to development of inoculants that are more potent at increasing fiber digestion.

Certain bacterial inoculants produce FAE. Nsereko et al. (2008) reported that treating perennial ryegrass with a FAE-producing lactic acid bacterium increased NDFD. Kang et al. (2009) reported that DM and NDFD of 1 of 2 corn silage hybrids was increased by treatment with an inoculant containing FAE-producing bacteria (Lactobacillus casei and Lactobacillus buchneri). In addition, Addah et al. (2011) reported that using a mixed bacterial culture containing $L$. buchneri LN4017 that produces FAE, and contains Lactobacillus plantarum and L. casei, increased ISNDF disappearance after 24 and $48 \mathrm{~h}$ of incubation by 40.5 and $14.5 \%$, respectively. Yet in their later study, feeding finishing steers barley silage using the same inoculant did not affect the growth performance and intake of steers (Addah et al., 2014). Other studies did not detect increases in NDFD when such inoculants where applied to alfalfa (Lynch et al., 2014) or corn silage (Lynch et al., 2015). The inconsistency in effects may be because expression of FAE depends on forage type and ensiling conditions (Muck et al., 2018) or because the targeted ester linkages are obstructed by the lignin polymer (Jung and Allen, 1995).

Inoculants containing enzymes or bacteria that secrete specific enzymes may be more expensive than those containing only bacteria (Table 2). In addition to their effects on NDFD, when determining their cost effectiveness, it is critical to consider their effects on the fermentation profile, DM recovery, and aerobic stability.

\section{Expansin Treatment}

Expansins and expansin-like proteins are a recently discovered group of nonhydrolytic proteins with the unique ability to induce cell-wall relaxation or loosening (Cosgrove, 2000, Georgelis et al., 2011; see Appendix Table A1). They are relatively small proteins (between $\sim 26$ to $28 \mathrm{kDa}$ ) with disruptive activity that weakens cellulose fibers, thereby enhancing hydrolysis by cellulases and hemicellulases (Kim et al., 2009; Georgelis et al., 2011; Silveira and Skaf, 2016). Structurally expansins are torpedo-shaped proteins with 2 domains; a distinctive feature is the 6 -stranded double-psi $\beta$-barrel domain, which is closely related to the glycosyl hydrolase 45 family of enzymes. However, unlike in fibrolytic enzymes, the GH45 in expansins lacks $\beta-1-4$ glucanase activity (Georgelis et al., 2011; Cosgrove, 2015). Plant expansins can be divided in 2 major families, $\alpha$-expansins and $\beta$-expansins. However, only the $\alpha$ family has cell wall relaxing or loosening activity during acid growth (i.e., growth under acidic conditions), whereas $\beta$ has been identified as a family of pollen allergens (Cosgrove, 2015). In bacterial and fungal genomes, similar proteins with loosening activity were discovered later because they lack conserved regions commonly found in plant expansins (Cosgrove, 2015; Liu et al., 2015). In addition to expansins and expansin-like proteins, loosenins and swollenins are cell wall disruptive-type proteins (Liu et al., 2015) that differ from expansins because swollenins possess endoglucanase activity (Chen et al., 2010; Cosgrove, 2015), and loosenins are smaller, have only 1 domain with a double-psi $\beta$-barrel domain fold, and are less active than expansins (Quiroz-Castañeda et al., 2011).

Bacterial expansin-like proteins (BsEXLX1) from Bacillus subtilis have been used as the gold standard to study the chaotropic or hydrogen-bonding disrupting effects of expansins and expansin-like proteins on hydrolysis of cellulose. This is because they can be more easily expressed in Escherichia coli than other types of proteins (Liu et al., 2015; Silveira and Skaf, 2016). Perhaps the most remarkable characteristic of expansins and expansin-like proteins is their ability to synergize with EFE to increases hydrolysis of cellulose and hemicellulose (Kim et al., 2009; Bunterngsook et al., 2015; Liu et al., 2015). Previous studies have demonstrated that synergistic effects between BsEXLX1 and EFE increased hydrolysis of cellulose and hemicellulose more than 5-fold compared with EFE alone (Kim et al., 2009; Bunterngsook et al., 2015; Liu et al., 2015). Recently, it was demonstrated that BsEXLX1 has greater affinity toward substrates with high concentrations of lignin (Kim et al., 2013), which further confirms that they may be particularly effective at increasing the efficacy of EFE at digesting the forage lignocellulose complex, particularly in $\mathrm{C}_{4}$ grasses and legumes, which tend to be more lignified than $\mathrm{C}_{3}$ grasses.

Most of the previous research on expansins and expansin-like proteins has been part of biofuel research rather than animal nutrition research. The recombinant expression of expansin and expansin-like protein is currently the only viable method to study these proteins due to the lack of commercially available products and the fact that only small quantities of expansin-like proteins are produced by microbes $(<30 \mu \mathrm{g} / \mathrm{L}$, Liu et al., 2015). Preliminary studies have shown that synergistic effects between EFE and BsEXLX1 increased hydrolysis of cellulose-based but not hemicellulose-based substrates under ruminal conditions (Pech-Cervantes et al., 2017a). To confirm if such findings applied in forages, a pilot study was conducted to compare the effects of a low dose of BsEXLX1 (165 $\mu \mathrm{g} / \mathrm{g}$ of DM) and 
an EFE with low cellulase activity ( $\sim 10 \%$ of the total enzyme activity; applied at $2.3 \mathrm{mg} / \mathrm{g}$ of $\mathrm{DM}$ ) on in vitro digestibility of bermudagrass silage. The IVDMD and IVNDFD of bermudagrass silage were synergistically increased by approximately 4 and $16 \%$, respectively, by applying both additives instead of the EFE alone (Pech-Cervantes et al., 2017a). The magnitude of the improvement for both IVDMD and IVNDFD was equal to that from using twice the dose of EFE in an earlier study (Romero et al., 2015b). However, as in a previous study (Kim et al., 2009), high doses of BsEXLX1 (above $400 \mu \mathrm{g} / \mathrm{g}$ of DM) decreased the efficacy of EFE at hydrolyzing NDF and decreased VFA production during in vitro fermentation of bermudagrass silage (PechCervantes et al., 2017b). The fact that lower doses of EFE seem to be more effective at eliciting the synergistic response with BsEXLX1 is beneficial because EFE are typically applied at low doses to ruminant diets (McAllister et al., 2001; Romero et al., 2016; Arriola et al., 2017). Though BsEXLX1 has also synergized with EFE to increase fiber hydrolysis and digestibility of a TMR for dairy cows, no effects were apparent when corn silage was examined (Pech-Cervantes et al., 2018; Figure 1), perhaps due to negative associated effects of starch on fiber digestion. In fact, BsEXLX1 has shown higher affinity toward lignocellulose substrates versus other proteins (Kim et al., 2013).

These preliminary results suggest that addition of BsEXLX1 could increase the efficacy of EFE at improving fiber digestion of certain forages and TMR by ruminants. More efficient methods of producing BsEXLX1 are required to supply sufficient quantities for testing in cattle diets. In this context, production

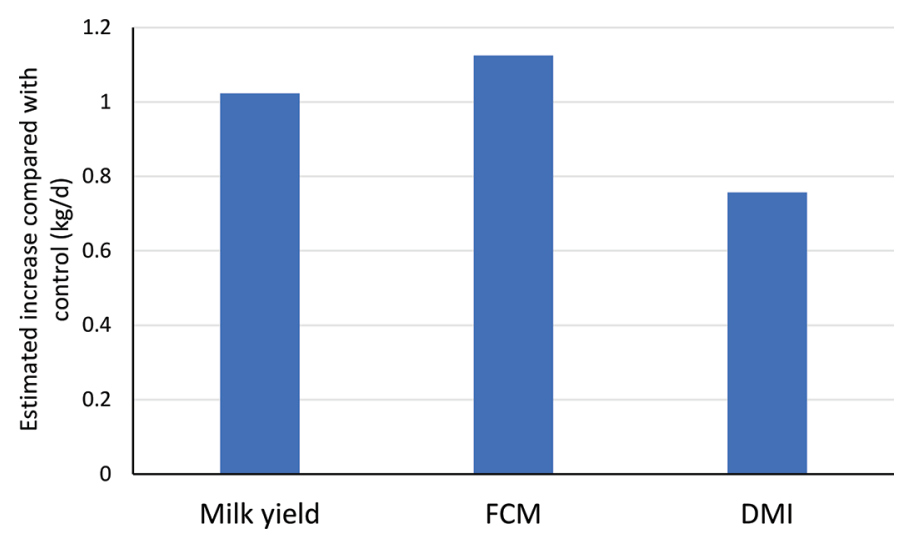

Figure 1. Estimated effects of expansin treatment of forages on animal performance measures estimated from in vitro or in situ NDF digestibility measures (Pech-Cervantes et al., 2018). To estimate animal performance measures, the relationship of Oba and Allen (1999) was used (i.e., a 1-unit increase in NDF digestibility in vitro or in situ was associated with a $0.17-\mathrm{kg}$ increase in DMI and a $0.25-\mathrm{kg}$ increase in $4 \% \mathrm{FCM})$. of expansins using genetically modified plants seems promising (Yoon et al., 2016). Yoon et al. (2016) successfully expressed $1,000 \%$ more expansin, cEXPA1, from cucumber gene in transgenic corn plants compared with traditional methods including purification by column affinity. In addition, synergies between the cellulase and plant expansin from cucumber (cEXPA1) increased hydrolysis of corn stover and tobacco leaves 2.5 -fold. The authors suggested that transgenics may offer the least expensive method to produce expansins at a large scale, even though expression of cEXPA1 in corn plants has not always been successful. Future research should also consider the potential of having expansins produced by live microbes that secrete them.

\section{Yeast or Yeast Culture or Yeast Fermentation Product Supplementation}

Yeast products are feed additives used in many parts of the world to improve animal performance. They include live yeast and yeast culture or fermentation products that can be produced from different strains of Saccharomyces cerevisiae. Various studies have shown that yeast products improved fiber utilization and animal performance (Marden et al., 2008; Ferraretto et al., 2012; Jiang et al., 2017a). However, some studies have shown that yeast products did not improve nutrient digestibility (Ouellet and Chiquette, 2016), dairy cow performance (Ferraretto et al., 2012; Bayat et al., 2015), or ruminal fermentation and microbiome composition (Mullins et al., 2013; Bayat et al., 2015). A meta-analysis by Desnoyers et al. (2009) showed that supplementing live yeast increased OM digestibility by 0.8 percentage units, DMI by $0.44 \mathrm{~kg} / \mathrm{d}$, and milk yield by $1.2 \mathrm{~kg} / \mathrm{d}$ by dairy cows. Similarly, in a meta-analysis by Poppy et al. (2012), yeast culture supplementation increased milk and milk fat and protein yields by 1.18 , 0.06 , and $0.03 \mathrm{~kg} / \mathrm{d}$. Increases in milk production by yeast supplementation may be due to improvement in fiber utilization. Plata and Bárcena-Gama (1994) reported that addition of $10 \mathrm{~g} /$ head per day of $S$. cerevisiae yeast culture improved NDFD from 48.6 to $60.5 \%$ in Holstein steers fed oat straw-based diets. Similarly, Marden et al. (2008) reported that live $S$. cerevisiae yeast increased total-tract $\mathrm{OM}, \mathrm{NDF}$, and ADF digestibilities from 62.2 to $66.6 \%, 29.6$ to $41.6 \%$, and 18.1 to $32.3 \%$, respectively. In addition, Ferraretto et al. (2012) also reported an increase in total-tract DM and NDF digestibilities and a tendency to increase milk fat content when $4 \mathrm{~g}$ /head per day of live yeast was supplemented to cows fed a high-starch (30\%) diet. In the study by Jiang et al. (2017a), feeding live yeast increased digestibility of DM (64.5 to $69.1 \%)$, NDF (45 to $54.5 \%$ ), $\mathrm{ADF}$ (53.1 to $60.9 \%$ ), as well as milk yield 
(by $2.1 \mathrm{~kg} / \mathrm{d}$ ) by dairy cows. In the same study, feeding killed yeast tended to increase digestibility of NDF and ADF but did not affect milk yield (Jiang et al., 2017a).

Effects of yeast supplementation are more evident when high-grain diets are fed due to the ability of yeast to modulate rumen $\mathrm{pH}$ during acidosis. For example, AlZahal et al. (2014) reported that yeast supplementation was more effective at improving ruminal $\mathrm{pH}$, total VFA production, milk production, and DMI when lactating dairy cows were fed a low-forage (49\%) diet rather than a high-forage $(77 \%)$ diet.

Yeast supplementation has decreased lactate production and enhanced lactate utilization (Lynch and Martin, 2002; Chaucheyras-Durand et al., 2005; Fonty and Chaucheyras-Durand, 2006), thereby stabilizing ruminal $\mathrm{pH}$ and increasing $\mathrm{NDFD}$, as observed earlier (Marden et al., 2008). In addition, live yeast have the ability to scavenge $\mathrm{O}_{2}$ and reduce the redox potential of ruminal fluid (Newbold et al., 1996). These changes supposedly make the ruminal environment more conducive for the growth of anaerobic microorganisms including cellulolytic bacteria (Newbold et al., 1996; Jouany et al., 1998; Chaucheyras-Durand and Fonty, 2001; Marden et al., 2008).

Additionally, yeast product supplementation may provide soluble growth factors such as vitamin $\mathrm{B}, \mathrm{AA}$, and organic acids that are beneficial for the growth of major cellulolytic bacteria such as Ruminococcus albus and Fibrobacter succinogens, which increase the initial digestion rate of cellulose (Callaway and Martin, 1997). That yeast supplementation increases abundance of cellulolytic bacteria has been confirmed in vitro (Chaucheyras et al., 1995; Newbold et al., 1998; Lila et al., 2004) and more recently in vivo using metagenomics (Pinloche et al., 2013; Jiang et al., 2017b). A recent study by AlZahal et al. (2017; Figure 2) used metatranscriptomics to measure enzyme activity in the rumen and showed that feeding active dry yeast increased abundance of mRNA for endo- $\beta$-1,4-glucanase, and tended to increase that of $\alpha$-glucuronidase. These studies show that yeast may improve the abundance and enzyme activity of cellulolytic bacteria.

The beneficial effects of yeast on fiber digestion and animal performance are not limited to effects on cellulolytic bacteria, but they are attributable also to manipulation of ruminal microorganisms including fungi and protozoa. Chaucheyras et al. (1995) found that live yeast stimulated the growth of the fungus Neocallimastix frontalis, which is known to have cellulolytic activity, in a vitamin-deficient medium. In addition, Chaucheyras-Durand and Fonty (2002) reported that protozoa were established earlier when live yeast were fed to lambs. Similarly, Ding et al. (2014) reported that yeast supplementation increased the population of pro- tozoa, fungi, as well as some lactate-utilizing bacteria. Recent metagenomics studies showed that live yeast supplementation changed the abundance of unknown/ uncultured bacteria in addition to increasing the abundance of some cellulolytic bacteria, leading to increased digestibility of NDF (Pinloche et al., 2013; Jiang et al., 2017b). Jiang et al. (2017a,b) reported that live yeast supplementation increased NDFD and decreased the abundance of uncultured Lachnospiraceae and RFP 12 bacteria, which were negatively correlated with NDFD but positively correlated with feed efficiency (Figure 3 ), though their specific functions in the rumen are unknown. Research should more precisely identify and then culture these bacteria to understand better the beneficial effect of yeast on fiber digestion and performance of dairy cattle.

Overall, supplementation with live yeast or yeast culture increased milk yield by dairy cows (Table 1), but the magnitude of the response varies with the lactation stage of cows, the yeast product, diet composition, and stressors on the cow. Therefore, future studies should aim to optimize yeast products to achieve consistent improvements in fiber digestion and animal performance over a wide range of conditions. In addition, research should identify the relative importance of the main active ingredients of yeast products, particularly yeast cultures, to determine their mode of action.

\section{White- and Brown-Rot Fungi}

White-Rot Fungi. White-rot fungi achieve lignin depolymerization through the activity of their ligninolytic enzymes, which include lignin peroxidase, man-

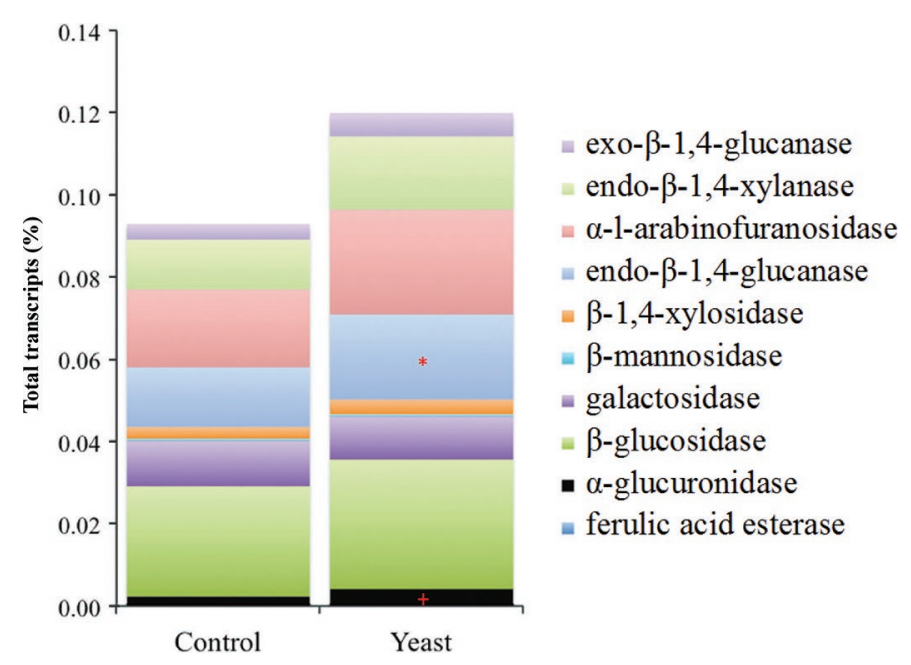

Figure 2. The effect of feeding active dry yeast on abundance of cellulase and hemicellulase enzymes in the rumen (adapted from AlZahal et al., 2017). ${ }^{*} P=0.02,+P=0.10$. 
ganese peroxidase, versatile peroxidase, laccase, and $\mathrm{H}_{2} \mathrm{O}_{2}$-forming enzymes [such as (methyl) glyoxal oxidase and aryl alcohol oxidase; Wong, 2009; Sindhu et al., 2016]. The manganese peroxidase and laccases act primarily on phenols but can metabolize the nonphenolic moieties under certain conditions (Rouches et al., 2016), whereas lignin peroxidase acts on the nonphenolic lignin components (up to $90 \%$ of the polymer), and versatile peroxidase acts on both phenolic and nonphenolic components (Martinez et al., 2005; Rouches et al., 2016). In addition, white-rot fungi also use extracellular reactive oxygen species (ROS), which may initiate lignocellulose decay, as lignocellulose-degrading enzymes are too large to penetrate an intact cell wall (Srebotnik et al., 1988; Blanchette et al., 1997). Reactions of these highly reactive oxygen species or free radicals are catalyzed by peroxidases produced by the white-rot fungi (Kersten et al., 1985; Shah et al., 1991; Barr and Aust, 1994). In particular, peroxidases catalyze reduction of oxygen to superoxide in reactions involving $\mathrm{H}_{2} \mathrm{O}_{2}$ and metabolites such as oxalates and veratryl alcohol (Akamatsu et al., 1990; Popp et al., 1990). The reaction also leads to the reduction of ferric iron, catalyzed by lignin peroxidase, generating ferrous iron, which could react with $\mathrm{H}_{2} \mathrm{O}_{2}$ to produce $\cdot \mathrm{OH}$ radicals (Barr et al., 1992) that can disrupt lignocellulose and allow penetration by lignocellulose-degrading enzymes.

In addition to ligninolytic enzymes, certain whiterot fungi also produce cellulose-degrading enzymes ( $\beta$-glucosidase, cellobiohydrolase, and $\beta$-xylosidase; Vrsanska et al., 2016), resulting in simultaneous degradation of lignin and cellulose components by several strains (Trametes versicolor, Heterobasidium annosum, and Irpex lacteus). Consequently, white-rot fungi can improve digestibility and nutritive value of low-quality forages such as wheat straw and bermudagrass (Akin et al., 1993; Nayan et al., 2018). Tuyen et al. (2012) reported that 9 of 11 species of white-rot fungi increased IVNDFD and in vitro ADF digestibility of wheat straw. However, excessive carbohydrate degradation is one of the main drawbacks to using some strains of whiterot fungi to improve utilization of fiber by ruminants (Wong, 2009; Sarnklong et al., 2010). Fortunately, some strains (Ceriporiopsis subvermispora, Phellimus pini, Phlebia spp., Lentinula edodes, Hericium clathroides, and Pleurotus spp.) selectively degrade lignin alone or preferentially, probably due to a lack of a complete cellulolytic enzymatic complex (Sethuraman et al., 1998; Guerra et al., 2003; Wong, 2009; van Kuijk et al., 2015). Such strains are clearly more likely to improve fiber di-

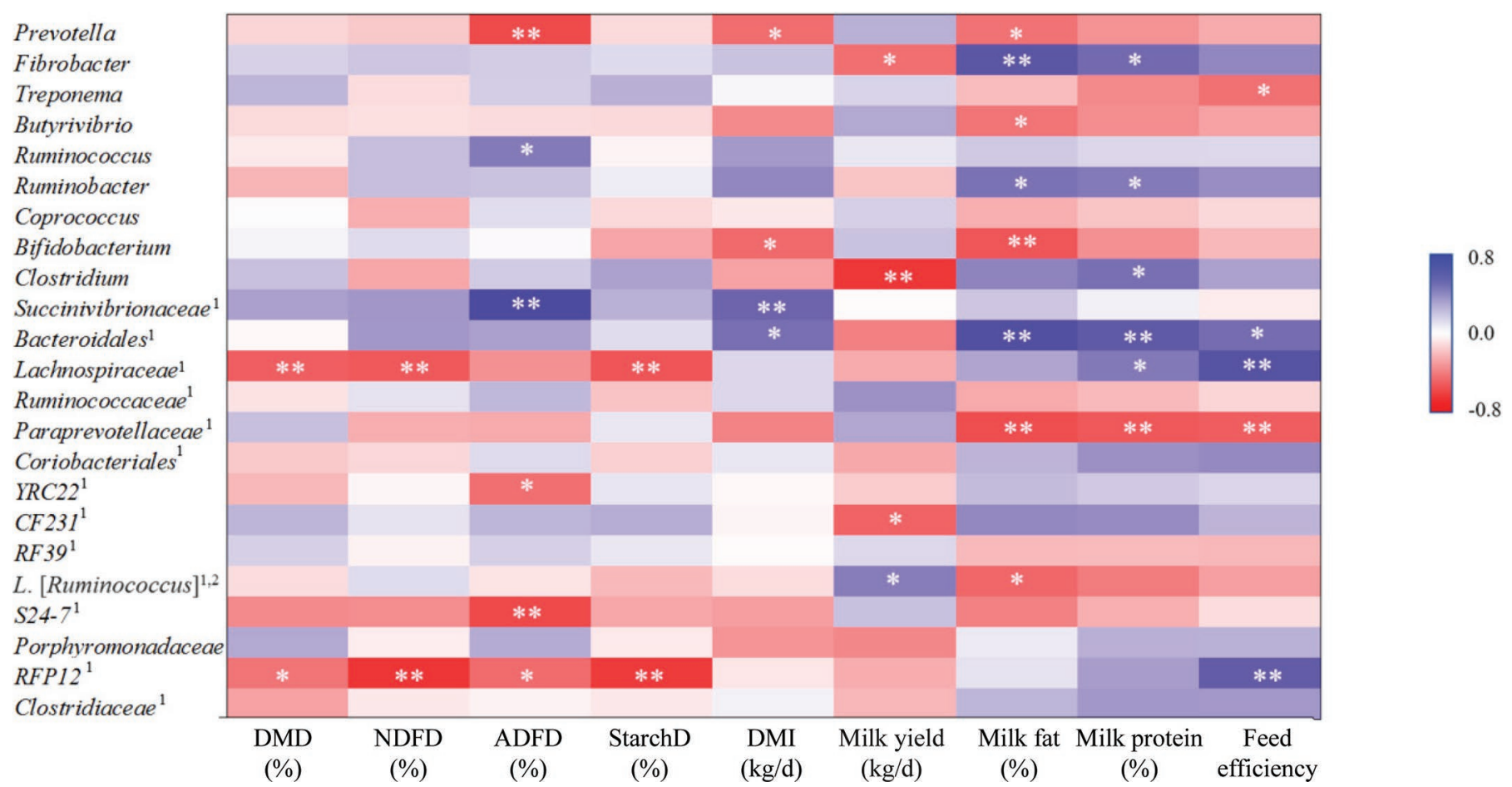

Figure 3. Pearson correlation between animal performance measurements and relative abundance of dominant bacteria ( $>0.5 \%$ of the bacterial population) in the solid fraction of rumen contents. ${ }^{1}$ Unknown genera in the respective family/order. ${ }^{2}$ The genus in brackets is a candidate taxon. Feed efficiency was calculated by dividing $3.5 \%$ FCM by DMI. ${ }^{*}$ Significant Pearson correlation coefficient $(P \leq 0.05)$. ${ }^{*}$ Pearson correlation coefficient tended to be significant $(0.05<P \leq 0.10)$. DMD, NDFD, ADFD, and StarchD $=$ DM, NDF, ADF, and starch digestibility, respectively. 
gestion and animal performance without adverse effects on carbohydrate utilization. For instance, lignin was selectively degraded (62.9\%) by Ceriporiopsis subvermispora (Tuyen et al., 2012) and similar results were observed in other studies (Guerra et al., 2003; Itoh et al., 2003). Nonetheless, considerable variability in fiber degradation potential exists among different strains of the same species. Nayan et al. (2018) examined effects of treatment of wheat straw treated with different strains of white-rot fungi. Lignin degradation was highest for a strain of C. subvermispora (CS1), which resulted in $52.2 \%$ more lignin degradation compared with the control, and also resulted in 6 and $49.7 \%$ more degradation of cellulose and hemicellulose, respectively, relative to the untreated wheat straw (control). However, $C$. subvermispora (CS12) treatment resulted in the lowest lignin degradation (17.5\% more than the control), with 2.4 and $31.8 \%$ more degradation of cellulose and hemicellulose, respectively, relative to the untreated wheat straw. Hence, it is essential to identify specific strains for fungal pretreatment experiments rather than focusing on species. Forage treatment with white-rot fungi will likely increase in vivo NDFD based on its ability to increase IVNDFD in previous studies (Figure 4).

Few studies have involved feeding white rot fungi to animals. A notable exception is the study of Fazaeli et al. (2004) in which treatment of wheat straw with a lignin-selective strain, Pleurotus ostreatus (P-41), increased DMI (12.2 vs. $10.6 \mathrm{~kg} / \mathrm{d}$ ), DMD (58.8 vs $52.3 \%$ ), NDFD (42.3 vs. $34.3 \%$ ), milk yield (9 vs. 7.5 $\mathrm{kg} / \mathrm{d}$ ), and BW gain (743 vs. $272 \mathrm{~g} / \mathrm{d}$ ) of dairy cattle in late lactation, when the treated and untreated straw were fed as $30 \%$ of a TMR. Similarly, Shrivastava et al. (2014) reported greater DMI (per kg of metabolic BW), DMD (57.82 vs. $52.07 \%$ ), NDFD (53.3 vs. $45.8 \%$ ), and $50 \mathrm{~g} / \mathrm{d}$ higher average BW gain, when buffalo calves were fed wheat straw treated with Crinipellis sp. RCK1 instead of untreated wheat straw, both of which were fed ad libitum and supplemented with a concentrate. Shahzad et al. (2016) also reported greater DMI and digestibility when white-rot fungi-treated wheat straw was used to replace $33 \%$ of the untreated wheat straw in a TMR fed to buffalo calves.

Despite these positive responses, white-rot fungi are not widely used for ruminant fiber digestion. This is partly due to the long pretreatment time required (van Kuijk et al., 2015) and, more importantly, the risk of degradation of cellulose and xylan, thus reducing the absolute nutrient content of the residual forage. Although careful strain selection can help minimize such reduction or loss in nutrient content, there are additional challenges with white rot fungi treatment: laccase is a potential inhibitor of cellulase activity (Moreno et al., 2012; Yingjie et al., 2018) and fungal

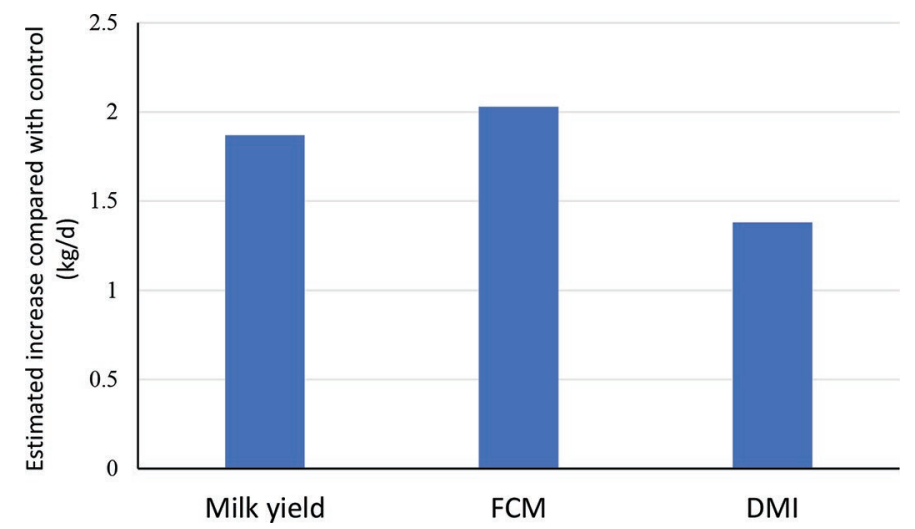

Figure 4. Estimated effects of white-rot fungi treatment of forages on animal performance measures estimated using in vitro or in situ NDF digestibility measurements (raw mean difference from Karunanandaa and Varga, 1996; Paul et al., 2004; Tao et al., 2016). To estimate animal performance measures, the relationship of Oba and Allen (1999) was used (i.e., a 1-unit increase in NDF digestibility in vitro or in situ was associated with a $0.17-\mathrm{kg}$ increase in DMI and a 0.25 -kg increase in $4 \% \mathrm{FCM}$ ).

delignification is an aerobic process (van Kuijk et al., 2015) that does not occur in the anerobic rumen. More research is needed on white-rot fungal strains that effectively delignify forages without laccase production and without sacrificing desirable carbohydrates.

Brown-Rot Fungi. Brown-rot fungi can degrade lignocellulose polysaccharides by supposedly modifying rather than removing lignin (Highley, 1991) and producing enzymes that selectively depolymerize cellulose and hemicellulose, leaving a brown-colored rot (Cowling, 1961; Gao et al., 2012). The modifications to lignin include demethylation, hydroxylation, and side chain oxidation (Martinez et al., 2011; Yelle et al., 2011; Arantes et al., 2012). Brown-rot fungi metabolize amorphous cellulose associated with lignin, leaving the crystalline cellulose (Eriksson et al., 1990; KlemanLeyer et al., 1992). The brown rot process involves an initial nonselective oxidation of lignocellulose components via an extracellular Fenton reaction in which reduced iron $\left(\mathrm{Fe}^{2+}\right)$ is oxidized by hydrogen peroxide $\left(\mathrm{H}_{2} \mathrm{O}_{2}\right)$, yielding ROS such as hydroxyl radicals $(\cdot \mathrm{OH})$. Activities of these ROS result in electron transfer from the lignocellulose complex, causing structural changes and depolymerization (Kerem et al., 1999; Arantes et al., 2012; Kaffenberger and Schilling, 2015). The destructive activity also increases the porosity of the lignocellulose matrix, making the polysaccharides more accessible to enzymatic actions (Flournoy et al., 1991). Following this, enzymatic hydrolysis of the polysaccharide occurs, releasing digestible sugars that can be metabolized by the fungi (Arantes et al., 2012). Examples of brown-rot fungi include Gloeophyllum trabeum, Fomitopsis lilacino-gilva, Laetiporus portentosus, Postia 
placenta, Piptoporus betulinus, and Serpula lacrimans (Wong, 2009), but G. trabeum is the most studied species (Hatakka, 2001). Despite the destructive potential of ROS against cells or lignocellulase, they may have relatively little adverse effects on humans, animals, or the environment. Because they are aerobic organisms, their biological activities cease once they get to the rumen. Second, these ROS generally have an extremely short half-life, for example, the half-life for $\cdot \mathrm{OH}$ is about $10^{-9} \mathrm{~s}$ because of its high reactivity (Arantes et al., 2012; Gligorovski et al., 2015). Consequently, the concentration of these ROS decreases rapidly after treatment. Furthermore, any residual deleterious effects of ROS can be neutralized by the human or animal body's antioxidants (Arora et al., 2011).

Several studies have used brown-rot fungi to pretreat biomass for biofuel production, but few animal nutrition studies have used them to increase fiber utilization in ruminant diets. Gao et al. (2012) pretreated corn stover with different strains of white- and brown- rot fungi and reported that the greatest conversion of cellulose to glucose occurred with a strain of brown-rot fungi, G. trabeum (KU-41), after $20 \mathrm{~d}$ of pretreatment. These authors reported 32.0 and $31.4 \%$ conversion of xylan to xylose with 2 strains of $G$. trabeum, KU-41 and NBRC6430, respectively, compared with $11.2 \%$ for the control treatment, after $48 \mathrm{~h}$ of enzymatic hydrolysis. The authors also reported 47 and $42 \%$ increases in cellulose saccharification with KU-41 and NBRC6430, respectively, despite an increase in the ratio of lignin to carbohydrates in the pretreated corn stover. This increased saccharification of cellulose in spite of an increase in proportion of lignin to carbohydrates supports the hypothesis that enzymatic access to cellulose is more closely associated with hemicellulose disintegration and modification of lignin structure than to actual delignification (Öhgren et al., 2007; Kumar and Wyman, 2009; Gao et al., 2012). In another study, when corn stalk, pine, and aspen were pretreated with 5 different species of brown-rot fungi, the greatest glucan saccharification yield was recorded for aspen pretreated with $G$.trabeum (ATCC 11539), with the yield increasing and reaching its peak $(44.7 \%)$ at wk 6 of pretreatment. The opposite was observed for corn stover, as it had the greatest initial glucan yield, which reduced with progressing week of pretreatment, implying cellulose metabolism by the fungi. The authors also reported up to $40 \%$ lignin removal in the angiosperms (aspen and corn stover), whereas much of the lignin was retained in the gymnosperm (pine), prompting the suggestion that contrary to the commonly held belief that brown-rot fungi cause negligible lignin loss, delignification may have been underestimated, especially for angiosperms. The greater than usual lignin loss by brown-rot fungi with the an- giosperms are probably due to the greater syringyl to guaiacyl phenol ratio of angiosperm lignin, given that the brown-rot fungi are thought to preferentially attack the syringyl lignin unit (Hedges et al., 1988; Baucher et al., 1998; Kaffenberger and Schilling, 2015). Agosin et al. (1989) reported also that lignin modification by brown-rot fungi, such as its oxidation, can increase its hydrophilic groups, which could increase its solubility, and thus, the overall lignin loss.

Only a few studies have examined effects of brown-rot fungi treatment on digestibility of forage or byproduct fiber or other nutrients. El-Banna et al. (2010) reported that in vivo digestibility of $\mathrm{CP}, \mathrm{NDF}, \mathrm{ADF}$, hemicellulose and cellulose of sugarcane bagasse treated with the brown rot fungi, Trichoderma reesei (F-418), were increased compared with the untreated control, when fed to sheep. The authors reported that incubation of crop residues (bean straw, rice straw, corn stalk, and sugarcane bagasse) with $T$. reesei for $14 \mathrm{~d}$ decreased concentrations of NDF and ADF by 14.4 and $10.0 \%$, respectively. Furthermore, NDFD was increased when these authors (El-Banna et al., 2010) fed brown-rot fungi-treated bean straw to sheep. However, Nurjana et al. (2016) reported that a different T. reesei strain, QM6a, decreased NDF and ADF concentrations of Napier grass but did not affect NDFD.

That only few in vitro and in vivo studies have been conducted to examine digestibility improvements by brown-rot fungi are attributable to the long pretreatment time, the need for aerobic conditions for the treatment, and the fact that certain strains of brown-rot fungi degrade desirable polysaccharides, which could reduce the residual nutrient content of treated forages. More research is needed to identify strains that remove or modify lignin in ways that increase accessibility to cellulose and hemicellulose, without degrading these beneficial polysaccharides.

\section{CONCLUSIONS}

Using BMR hybrids has been among the most consistent, cost effective, and adopted strategies to increase forage fiber digestion and milk production by dairy cows. In this context, more research is needed to examine and validate the efficacy and cost effectiveness of other genetic technologies such as low-lignin alfalfa or grasses, seedling-ferulate ester mutants, and transgenic fibrolytic-enzyme secreting forages. Mechanical treatment methods that reduce forage particle size vary in effects on fiber digestibility depending on the particle size achieved. A balance between maintaining physical effectiveness of the fiber and reducing the particle size is critical for such approaches even when they increase intake and facilitate handling and transport 
of feeds. Chemical treatment methods of improving fiber digestibility are consistent and effective, but their widespread adoption has been limited by their caustic nature and cost. Among the biological treatment techniques, some (yeast products, enzymes, and inoculants) have increased fiber digestion and milk production by dairy cows in recent meta-analyses, though responses in individual studies have varied. Omic technologies should be exploited to make such products more potent and consistently effective. Other biological treatments (brown and white rot fungi) have considerable potential to improve fiber utilization provided selective strains are used that avoid or minimize carbohydrate degradation. Combination treatments such as AFEX or steampressure-thermal treatment can reduce the integrity of fiber and increase the digestibility but they are not feasible on farms, as they occur in reactors. More studies on the cost effectiveness of feeding the products are needed as well as studies on adapting the technology for on-farm use.

\section{ACKNOWLEDGMENTS}

Publication of this article was funded in part by the University of Florida Open Access Publishing Fund.

\section{REFERENCES}

Addah, W., J. Baah, C. Barkley, R. Wilde, E. K. Okine, and T. A. McAllister. 2011. Effects of applying a ferouyl esterase silage inoculant at ensiling on nutrient composition, in situ NDF disappearance and surface temperature of barley silage. Page 469 in Proc. 60th Annual Meeting of the Canadian Society of Animal Science, Halifax, Nova Scotia, Canada. Canadian Society of Animal Science, Toronto, ON, Canada.

Addah, W., J. Baah, E. K. Okine, F. N. Owens, and T. A. McAllister. 2014. Effects of chop-length and a ferulic acid esterase-producing inoculant on fermentation and aerobic stability of barley silage, and growth performance of finishing feedlot steers. Anim. Feed Sci. Technol. 197:34-46. https://doi.org/10.1016/j.anifeedsci.2014 .07 .012 .

Adesogan, A. T., Z. X. Ma, J. J. Romero, and K. G. Arriola. 2014. Ruminant Nutrition Symposium: Improving cell wall digestion and animal performance with fibrolytic enzymes. J. Anim. Sci. 92:1317-1330. https://doi.org/10.2527/jas.2013-7273.

Agosin, E., S. Jarpa, E. Rojas, and E. Espejo. 1989. Solid-state fermentation of pine sawdust by selected brown-rot fungi. Enzyme Microb. Technol. 11:511-517. https://doi.org/10.1016/0141 -0229(89)90033-1.

Akamatsu, Y., D. B. Ma, T. Higuchi, and M. Shimada. 1990. A novel enzymatic decarboxylation of oxalic acid by the lignin peroxidase system of white-rot fungus Phanerochaete chrysosporium. FEBS Lett. 269:261-263. https://doi.org/10.1016/0014-5793(90)81169 -O.

Akin, D. E. 1989. Histological and physical factors affecting digestibility of forages. Agron. J. 81:17-25. https://doi.org/10.2134/ agronj1989.00021962008100010004x.

Akin, D. E., A. Sethuraman, W. H. Morrison, S. A. Martin, and K. E. Eriksson. 1993. Microbial delignification with white rot fungi improves forage digestibility. Appl. Environ. Microbiol. 59:42744282.
Allen, M. S. 1996. Physical constraints on voluntary intake of forages by ruminants. J. Anim. Sci. 74:3063-3075. https://doi.org/10 $.2527 / 1996.74123063 x$.

Allen, M. S. 1997. Relationship between fermentation acid production in the rumen and the requirement for physically effective fiber. J. Dairy Sci. 80:1447-1462. https://doi.org/10.3168/jds.S0022 -0302(97)76074-0.

AlZahal, O., L. Dionissopoulos, A. H. Laarman, N. Walker, and B. W. McBride. 2014. Active dry Saccharomyces cerevisiae can alleviate the effect of subacute ruminal acidosis in lactating dairy cows. J. Dairy Sci. 97:7751-7763.

AlZahal, O., F. Li, N. D. Walker, and B. W. McBride. 2017. Factors influencing ruminal bacterial community diversity and composition and microbial fibrolytic enzyme abundance in lactating dairy cows with a focus on the role of active dry yeast. J. Dairy Sci. 100:4377-4393. https://doi.org/10.3168/jds.2016-11473.

Arantes, V., J. Jellison, and B. Goodell. 2012. Peculiarities of brownrot fungi and biochemical Fenton reaction with regard to their potential as a model for bioprocessing biomass. Appl. Microbiol. Biotechnol. 94:323-338. https://doi.org/10.1007/s00253-012-3954-y.

Arora, D. S., R. K. Sharma, and P. Chandra. 2011. Biodelignification of wheat straw and its effect on in vitro digestibility and antioxidant properties. Int. Biodeterior. Biodegradation 65:352-358. https://doi.org/10.1016/j.ibiod.2010.12.009.

Arriola, K. G., S. C. Kim, C. R. Staples, and A. T. Adesogan. 2011a. Effect of applying bacterial inoculants containing different types of bacteria to corn silage on the performance of dairy cattle. J. Dairy Sci. 94:3973-3979.

Arriola, K. G., A. S. Oliveira, Z. X. Ma, I. J. Lean, M. C. Giurcanu, and A. T. Adesogan. 2017. A meta-analysis on the effect of dietary application of exogenous fibrolytic enzymes on the performance of dairy cows. J. Dairy Sci. 100:4513-4527.

Arriola, K. G., J. J. Romero, and A. T. Adesogan. 2011b. Effects of $\mathrm{pH}$ and temperature on fibrolytic enzyme activities of various commercial exogenous enzyme preparations. J. Dairy Sci. 94(E-Suppl. 1):554. (Abstr.)

Aydin, G., R. J. Grant, and J. O'Rear. 1999. Brown midrib sorghum in diets for lactating dairy cows. J. Dairy Sci. 82:2127-2135. https: //doi.org/10.3168/jds.S0022-0302(99)75456-1.

Badhan, A., T. Wang, R. Gruninger, D. Patton, J. Powlowski, A. Tsang, and T. McAllister. 2014. Formulation of enzyme blends to maximize the hydrolysis of alkaline peroxide pretreated alfalfa hay and barley straw by rumen enzymes and commercial cellulases. BMC Biotechnol. 14:31. https://doi.org/10.1186/1472-6750-14-31.

Balasko, J. A., and C. J. Nelson. 2003. Grasses for northern areas. Pages 125-148 in Forages: An Introduction to Grassland Agriculture. M. Collins, ed. Iowa State Press, Ames.

Bals, B., H. Murnen, M. Allen, and B. Dale. 2010. Ammonia fiber expansion (AFEX) treatment of eleven different forages: improvements to fiber digestibility in vitro. Anim. Feed Sci. Technol. 155:147-155. https://doi.org/10.1016/j.anifeedsci.2009.11.004.

Bals, B., C. Wedding, V. Balan, E. Sendich, and B. Dale. 2011. Evaluating the impact of ammonia fiber expansion (AFEX) pretreatment conditions on the cost of ethanol production. Bioresour. Technol. 102:1277-1283. https://doi.org/10.1016/j.biortech.2010 .08.058.

Bansal, P., M. Hall, M. J. Realff, J. H. Lee, and A. S. Bommarius. 2009. Modeling cellulase kinetics on lignocellulosic substrates. Biotechnol. Adv. 27:833-848. https://doi.org/10.1016/j.biotechadv .2009.06.005

Bargo, F., L. D. Muller, J. E. Delahoy, and T. W. Cassidy. 2002. Performance of high producing dairy cows with three different feeding systems combining pasture and total mixed rations. J. Dairy Sci. 85:2948-2963.

Barr, D. P., and S. D. Aust. 1994. Mechanisms white rot fungi use to degrade pollutants. Environ. Sci. Technol. 28:78A-87A. https:// pubs.acs.org/doi/pdf/10.1021/es00051a724.

Barr, D. P., M. M. Shah, T. A. Grover, and S. D. Aust. 1992. Production of hydroxyl radical by lignin peroxidase from Phanerochaete chrysosporium. Arch. Biochem. Biophys. 298:480-485. https://doi .org/10.1016/0003-9861(92)90438-3. 
Batistoti, C., B. Lemp, L. Jank, M. Moris, A. C. Cubas, R. A. Gomes, and M. V. B. Ferreira. 2012. Correlations among anatomical, morphological, chemical and agronomic characteristics of leaf blades in Panicum maximum genotypes. Anim. Feed Sci. Technol. 171:173180. https://doi.org/10.1016/j.anifeedsci.2011.11.008.

Baucher, M., B. Monties, M. V. Montagu, and W. Boerjan. 1998. Biosynthesis and genetic engineering of lignin. CRC Crit. Rev. Plant Sci. 17:125-197. https://doi.org/10.1016/s0735-2689(98)00360-8.

Bayat, A. R., P. Kairenius, T. Stefanski, H. Leskinen, S. ComtetMarre, E. Forano, F. Chaucheyras-Durand, and K. J. Shingfield. 2015. Effect of camelina oil or live yeasts (Saccharomyces cerevisiae) on ruminal methane production, rumen fermentation, and milk fatty acid composition in lactating cows fed grass silage diets. J. Dairy Sci. 98:3166-3181. https://doi.org/10.3168/jds.2014-7976.

Beauchemin, K. A., D. Colombatto, D. P. Morgavi, and W. Z. Yang. 2003. Use of exogenous fibrolytic enzymes to improve feed utilization by ruminants. J. Anim. Sci. 81:E37-E47.

Beauchemin, K. A., and L. Holtshausen. 2010. Developments in enzyme usage in ruminants. Pages 206-230 in Enzymes in Farm Animal Nutrition. M. R. Bedford and G. G. Partridge ed. CAB International, Bodmin, UK.

Bernard, J. K., and S. Tao. 2015. Production response of lactating dairy cows to brachytic forage sorghum silage compared with corn silage from first or second harvest. J. Dairy Sci. 98:8994-9000.

Biswas, G. C. G., C. Ransom, and M. Sticklen. 2006. Expression of biologically active Acidothermus cellulolyticus endoglucanase in transgenic maize plants. Plant Sci. 171:617-623. https://doi.org/ 10.1016/j.plantsci.2006.06.004.

Blanchette, R. A., E. W. Krueger, J. E. Haight, A. Masood, and D. E. Akin. 1997. Cell wall alterations in loblolly pine wood decayed by the white-rot fungus, Ceriporiopsis subvermispora. J. Biotechnol. 53:203-213. https://doi.org/10.1016/s0168-1656(97)01674-x.

Blummel, M., B. Steele, and B. E. Dale. 2014. Opportunities from second-generation biofuel technologies for upgrading lignocellulosic biomass for livestock feed. Perspect. Agric. Vet. Sci. Nutr. Nat. Resour. 9:1-8. https://doi.org/10.1079/pavsnnr20149041.

Bonfante, E., A. Palmonari, L. Mammi, G. Canestrari, M. Fustini, and A. Formigoni. 2016. Effects of a completely pelleted diet on growth performance in Holstein heifers. J. Dairy Sci. 99:9724-9731. https: //doi.org/10.3168/jds.2016-11033.

Bosch, M. W., I. M. Janssen, I. van Bruchem, H. Boer, and G. Hof 1988. Digestion of alfalfa and grass silages in sheep I. Rates of fermentation in and passage from the reticulorumen. Neth. J. Agric. Sci. 36:175-178.

Brito, A. F., G. F. Tremblay, A. Bertrand, Y. Castonguay, G. Bélanger, R. Michaud, H. Lapierre, C. Benchaar, H. V. Petit, D. R. Ouellet, and R. Berthiaume. 2008. Alfalfa cut at sundown and harvested as baleage improves milk yield of late-lactation dairy cows. J. Dairy Sci. 91:3968-3982.

Brito, A. F., G. F. Tremblay, H. Lapierre, A. Bertrand, Y. Castonguay, G. Bélanger, R. Michaud, C. Benchaar, D. R. Ouellet, and R. Berthiaume. 2009. Alfalfa cut at sundown and harvested as baleage increases bacterial protein synthesis in late-lactation dairy cows. J. Dairy Sci. 92:1092-1107.

Broderick, G. A., A. F. Brito, and J. J. Olmos Colmenero. 2007. Effects of feeding formate-treated alfalfa silage or red clover silage on the production of lactating dairy cows. J. Dairy Sci. 90:1378-1391. https://doi.org/10.3168/jds.S0022-0302(07)71624-7.

Broderick, G. A., J. H. Yang, and R. G. Koegel. 1993. Effect of steam heating alfalfa hay on utilization by lactating dairy cows. J. Dairy Sci. 76:165-174.

Brown, W. F., and W. Kunkle. 1992. Improving the feeding value of hay by anhydrous ammonia treatment. Tech. Bull. No. BUL888. University of Florida, IFAS Extension. Gainesville, FL.

Brown, W. H., S. S. Khalaf, A. Marmolejo, R. S. Swingle, and F. M. Whiting. 1990. Partial replacement of alfalfa hay with chopped wheat straw in diets for lactating dairy cows. J. Dairy Sci. 73:31723177. https://doi.org/10.3168/jds.S0022-0302(90)79007-8.

Brunecky, R., M. J. Selig, T. B. Vinzant, M. E. Himmel, D. Lee, M. J. Blaylock, and S. R. Decker. 2011. In planta expression of $A$. cellulolyticus Cel5A endocellulase reduces cell wall recalcitrance in tobacco and maize. Biotechnol. Biofuels 4:1. https://doi.org/10 .1186/1754-6834-4-1.

Bunterngsook, B., L. Eurwilaichitr, A. Thamchaipenet, and V. Champreda. 2015. Binding characteristics and synergistic effects of bacterial expansins on cellulosic and hemicellulosic substrates. Bioresour. Technol. 176:129-135. https://doi.org/10.1016/j.biortech 2014.11.042.

Bunterngsook, B., W. Mhuantong, V. Champreda, A. Thamchaiphenet, and L. Eurwilaichitr. 2014. Identification of novel bacterial expansins and their synergistic actions on cellulose degradation. Bioresour. Technol. 159:64-71. https://doi.org/10.1016/j.biortech .2014.02.004.

Bunzel, M., J. Ralph, C. Funk, and H. Steinhart. 2005. Structural elucidation of new ferulic acid-containing phenolic dimers and trimers isolated from maize bran. Tetrahedron Lett. 46:5845-5850. https:/ /doi.org/10.1016/j.tetlet.2005.06.140.

Burns, J. C., H. F. Mayland, and D. S. Fisher. 2005. Dry matter intake and digestion of alfalfa harvested at sunset and sunrise. J. Anim. Sci. 83:262-270.

Callaway, E. S., and S. A. Martin. 1997. Effects of a Saccharomyces cerevisiae culture on ruminal bacteria that utilize lactate and digest cellulose. J. Dairy Sci. 80:2035-2044. https://doi.org/10 $.3168 /$ jds.S0022-0302(97)76148-4.

Cameron, M. G., M. R. Cameron, G. C. Fahey Jr., J. H. Clark, L. L. Berger, and N. R. Merchen. 1991a. Effects of treating oat hulls with alkaline hydrogen peroxide on intake and digestion by midlactation dairy cows. J. Dairy Sci. 74:177-189. https://doi.org/10 .3168/jds.S0022-0302(91)78159-9.

Cameron, M. G., G. C. Fahey Jr., J. H. Clark, N. R. Merchen, and L. L. Berger. 1990. Effects of feeding alkaline hydrogen peroxidetreated wheat straw diets on digestion and production by dairy cows. J. Dairy Sci. 73:3544-3554. https://doi.org/10.3168/jds .S0022-0302(90)79054-6.

Cameron, M. G., G. C. Fahey Jr., J. H. Clark, N. R. Merchen, and L. L. Berger. 1991b. Effects of feeding alkaline hydrogen peroxide-treated wheat straw-based diets on intake, digestion, ruminal fermentation, and production responses by mid-lactation dairy cows. J. Anim. Sci. 69:1775-1787. https://doi.org/10.2527/1991 $.6941775 \mathrm{x}$

Campbell, T. J., F. Teymouri, B. Bals, J. Glassbrook, C. D. Nielson, and J. Videto. 2013. A packed bed ammonia fiber expansion reactor system for pretreatment of agricultural residues at regional depots. Biofuels 4:23-34. https://doi.org/10.4155/bfs.12.71.

Canale, C. J., S. M. Abrams, L. D. Muller, W. L. Kjelgaard, P. M. Anderson, and H. W. Harpster. 1988. Alkali-treated forage for early lactation dairy cows: Effects on lactation performance and nutrient digestibility. J. Dairy Sci. 71:2166-2174. https://doi.org/ 10.3168/jds.S0022-0302(88)79789-1.

Casler, M. D., and H. J. G. Jung. 1999. Selection and evaluation of smooth bromegrass clones with divergent lignin and etherified ferulic acid concentration. Crop Sci. 39:1866-1873. https://doi.org/ 10.2135/cropsci1999.3961866x.

Casperson, B. A., A. E. Wetz-Lutz, J. L. Dunn, and S. S. Donkin. 2018. Inclusion of calcium hydroxide-treated corn stover as a partial forage replacement in diets for lactating dairy cows. J. Dairy Sci. 101:2027-2036. https://doi.org/10.3168/jds.2017-13180.

Chaucheyras, F., G. Fonty, G. Bertin, and P. Gouet. 1995. Effects of live Saccharomyces cerevisiae cells on zoospore germination, growth, and cellulolytic activity of the rumen anaerobic fungus, Neocallimastix frontalis MCH3. Curr. Microbiol. 31:201-205. https: //doi.org/10.1007/bf00298373.

Chaucheyras-Durand, F., and G. Fonty. 2001. Establishment of cellulolytic bacteria and development of fermentative activities in the rumen of gnotobiotically-reared lambs receiving the microbial additive Saccharomyces cerevisiae CNCM I-1077. Reprod. Nutr. Dev. 41:57-68. https://doi.org/10.1051/rnd:2001112.

Chaucheyras-Durand, F., and G. Fonty. 2002. Influence of a probiotic yeast (Saccharomyces cerevisiae CNCM I-1077) on microbial colonization and fermentation in the rumen of newborn lambs. Microb. Ecol. Health Dis. 14:30-36. https://doi.org/10.1080/ 089106002760002739 . 
Chaucheyras-Durand, F., S. Masseglia, and G. Fonty. 2005. Effect of the microbial feed additive Saccharomyces cerevisiae CNCM I-1077 on protein and peptide degrading activities of rumen bacteria grown in vitro. Curr. Microbiol. 50:96-101. https://doi.org/10 .1007/s00284-004-4433-1.

Chaudhry, A. 1998. In vitro and in sacco digestibility of wheat straw treated with calcium oxide and sodium hydroxide alone or with hydrogen peroxide. Anim. Feed Sci. Technol. 74:301-313. https:// doi.org/10.1016/s0377-8401(98)00177-1.

Chen, X., N. Ishida, N. Todaka, R. Nakamura, J. Maruyama, H. Takahashi, and K. Kitamoto. 2010. Promotion of efficient saccharification of crystalline cellulose by Aspergillus fumigatus Swo1. Appl. Environ. Microbiol. 76:2556-2561. https://doi.org/10.1128/AEM .02499-09.

Cherney, J. H., and G. C. Marten. 1982. Small grain crop forage potential: II. Interrelationships among biological, chemical, morphological, and anatomical determinants of quality. Crop Sci. 22:240-243. https://doi.org/10.2135/cropsci1982.0011183x002200020010x.

Chesson, A. 1988. Lignin-polysaccharide complexes of the plant cell wall and their effect on microbial degradation in the rumen. Anim. Feed Sci. Technol. 21:219-228. https://doi.org/10.1016/0377 -8401(88)90104-6.

Clifton, C. M., W. J. Miller, and N. W. Cameron. 1967. Coastal bermudagrass as pellets and silage compared to oats-ryegrass-crimson clover, sudangrass, and corn silages with high and low grain levels for lactating cows. J. Dairy Sci. 50:1798-1804. https://doi.org/10 $.3168 /$ jds.S0022-0302(67)87718-X.

Coleman, S. W., J. E. Moore, and J. R. Wilson. 2004. Quality and utilization. Pages 267-308 in Warm Season $\left(\mathrm{C}_{4}\right)$ Grasses. L. E. Moser, B. L. Burson, and L. E. Sollenberger, ed. ASA, CSSA, and SSSA, Madison, WI.

Colombatto, D., and K. A. Beauchemin. 2003. A proposed methodology to standardize the determination of enzymic activities present in enzyme additives used in ruminant diets. Can. J. Anim. Sci. 83:559-568.

Colombatto, D., F. L. Mould, M. K. Bhat, D. P. Morgavi, K. A. Beauchemin, and E. Owen. 2003. Influence of fibrolytic enzymes on the hydrolysis and fermentation of pure cellulose and xylan by mixed ruminal microorganisms in vitro. J. Anim. Sci. 81:10401050. https://doi.org/10.2527/2003.8141040x.

Cook, D. E., R. W. Bender, K. J. Shinners, and D. K. Combs. 2016a. The effects of calcium hydroxide-treated whole-plant and fractionated corn silage on intake, digestion, and lactation performance in dairy cows. J. Dairy Sci. 99:5385-5393. https://doi.org/10.3168/ jds.2015-10402.

Cook, D. E., D. K. Combs, P. H. Doane, M. J. Cecava, and M. B. Hall. 2016b. The effects on digestibility and ruminal measures of chemically treated corn stover as a partial replacement for grain in dairy diets. J. Dairy Sci. 99:6342-6351. https://doi.org/10.3168/ jds.2015-10403.

Cosgrove, D. J. 2000. Loosening of plant cell walls by expansins. Nature 407:321-326. https://doi.org/10.1038/35030000.

Cosgrove, D. J. 2001. Enhancement of accessibility of cellulose by expansins. US Patent 6326470 B1.

Cosgrove, D. J. 2015. Plant expansins: Diversity and interactions with plant cell walls. Curr. Opin. Plant Biol. 25:162-172. https://doi .org/10.1016/j.pbi.2015.05.014.

Cowling, E. B. 1961. Comparative biochemistry of decay of sweetgum sapwood by white-rot and brown-rot fungi. USDA Technical Bulletin 1258:1-79.

Dado, R. G., and M. S. Allen. 1995. Intake limitations, feeding behavior, and rumen function of cows challenged with rumen fill from dietary fiber or inert bulk. J. Dairy Sci. 78:118-133. https://doi .org/10.3168/jds.S0022-0302(95)76622-X.

Dai, X., Y. Tian, J. Li, X. Su, X. Wang, S. Zhao, L. Liu, Y. Luo, D. Liu, H. Zheng, J. Wang, Z. Dong, S. Hu, and L. Huang. 2015. Metatranscriptomic analyses of plant cell wall polysaccharide degradation by microorganisms in the cow rumen. Appl. Environ. Microbiol. 81:1375-1386. https://doi.org/10.1128/AEM.03682-14.

Dann, H. M., R. J. Grant, K. W. Cotanch, E. D. Thomas, C. S. Ballard, and R. Rice. 2008. Comparison of brown midrib sorghum- sudangrass with corn silage on lactational performance and nutrient digestibility in Holstein dairy cows. J. Dairy Sci. 91:663-672. https://doi.org/10.3168/jds.2007-0521.

Dean, D. B., A. T. Adesogan, N. A. Krueger, and R. C. Littell. 2008. Effects of treatment with ammonia or fibrolytic enzymes on chemical composition and ruminal degradability of hays produced from tropical grasses. Anim. Feed Sci. Technol. 145:68-83. https://doi .org/10.1016/j.anifeedsci.2007.05.053.

Dean, D. B., C. R. Staples, R. C. Littell, S. C. Kim, and A. T. Adesogan. 2013. Effect of method of adding a fibrolytic enzyme to dairy cow diets on feed intake digestibility, milk production, ruminal fermentation, and blood metabolites. Anim. Nutr. Feed Technol. 13:287-302

Desnoyers, M., S. Giger-Reverdin, G. Bertin, C. Duvaux-Ponter, and D. Sauvant. 2009. Meta-analysis of the influence of Saccharomyces cerevisiae supplementation on ruminal parameters and milk production of ruminants. J. Dairy Sci. 92:1620-1632. https://doi.org/ $10.3168 /$ jds.2008-1414.

Ding, G., C. Ying, L. Zhao, Z. Zhou, L. Ren, and Q. Meng. 2014. Effect of Saccharomyces cerevisiae on alfalfa nutrient degradation characteristics and rumen microbial populations of steers fed diets with different concentrate-to-forage ratios. J. Anim. Sci. Biotechnol. 5:24. https://doi.org/10.1186/2049-1891-5-24.

Donnelly, D. M., L. C. de Resende, D. E. Cook, R. H. Atalla, and D. K. Combs. 2018. Technical note: A comparison of alkali treatment methods to improve neutral detergent fiber digestibility of corn stover. J. Dairy Sci. 101:9058-9064. https://doi.org/10.3168/jds .2017-14317.

Ebling, T. L., and L. Kung Jr.. 2004. A comparison of processed conventional corn silage to unprocessed and processed brown midrib corn silage on intake, digestion, and milk production by dairy cows. J. Dairy Sci. 87:2519-2526. https://doi.org/10.3168/jds .S0022-0302(04)73376-7.

El-Banna, H. M., A. S. Shalaby, G. M. Abdul-Aziz, M. Fadel, and W. M. A. Ghoneem. 2010. Effect of diets containing some biologically treated crop residues on performance of growing sheep. Egypt. J. Nutr. Feeds 13:21-36.

Engels, F. M., and H. J. G. Jung. 2005. Alfalfa stem tissues: Impact of lignification and cell length on ruminal degradation of large particles. Anim. Feed Sci. Technol. 120:309-321. https://doi.org/ 10.1016/j.anifeedsci.2005.03.003.

Eriksson, K. E., R. A. Blanchette, and P. Ander. 1990. Microbial and enzymatic degradation of wood and wood components. Springer, Berlin, Germany.

Eun, J. S., and K. A. Beauchemin. 2007. Enhancing in vitro degradation of alfalfa hay and corn silage using feed enzymes. J. Dairy Sci. 90:2839-2851. https://doi.org/10.3168/jds.2006-820.

Evert, R. F. 2006. Esau's Plant Anatomy, Meristems, Cells and Tissues of the Plant Body: Their Structure, Function, and Development. 3rd ed. John Wiley \& Sons Inc., Hoboken, NJ.

Fales, S. L., and J. O. Fritz. 2007. Factors affecting forage quality. Pages 569-580 in Forages, Volume II: The Science of Grassland Agriculture. 6th ed. R. F. Barnes, C. J. Nelson, K. J. Moore, and M. Collins, ed. Blackwell Publishing, Ames, IA.

Fazaeli, H., H. Mahmodzadeh, Z. A. Jelan, Y. Rouzbehan, J. B. Liang, and A. Azizi. 2004. Utilization of fungal treated wheat straw in the diet of late lactating cow. Asian-australas. J. Anim. Sci. $17: 467-472$.

Ferraretto, L. F., B. A. Saylor, J. P. Goeser, and K. A. Bryan. 2018. Case study: Effect of type of processor on corn silage processing score in samples of whole-plant corn silage. Prof. Anim. Sci. 34:293-298. https://doi.org/10.15232/pas.2017-01719.

Ferraretto, L. F., and R. D. Shaver. 2012a. Effect of corn shredlage on lactation performance and total tract starch digestibility by dairy cows. Prof. Anim. Sci. 28:639-647. https://doi.org/10.15232/ S1080-7446(15)30423-X

Ferraretto, L. F., and R. D. Shaver. 2012b. Meta-analysis: Impact of corn silage harvest practices on intake, digestion and milk production by dairy cows. Prof. Anim. Sci. 28:141-149. https://doi.org/ 10.15232/S1080-7446(15)30334-X. 
Ferraretto, L. F., and R. D. Shaver. 2015. Effects of whole-plant corn silage hybrid type on intake, digestion, ruminal fermentation, and lactation performance by dairy cows through a meta-analysis. J. Dairy Sci. 98:2662-2675. https://doi.org/10.3168/jds.2014-9045.

Ferraretto, L. F., R. D. Shaver, and S. J. Bertics. 2012. Effect of dietary supplementation with live-cell yeast at two dosages on lactation performance, ruminal fermentation, and total-tract nutrient digestibility in dairy cows. J. Dairy Sci. 95:4017-4028. https://doi .org/10.3168/jds.2011-5190

Filya, I., and E. Sucu. 2010. The effects of lactic acid bacteria on the fermentation, aerobic stability and nutritive value of maize silage. Grass Forage Sci. 65:446-455. https://doi.org/10.1111/j.1365-2494 .2010.00763.x.

Fisher, D. S., H. F. Mayland, and J. C. Burns. 2002. Variation in ruminant preference for alfalfa hays cut at sunup and sundown. Crop Sci. 42:231-237.

Fleischman, R. W., J. R. Baker, M. Hagopian, G. G. Wade, D. W. Hayden, E. R. Smith, J. H. Weisburger, and E. K. Weisburger. 1980. Carcinogenesis bioassay of acetamide, hexanamide, adipamide, urea and para-tolylurea in mice and rats. J. Environ. Pathol. Toxicol. 3:149-170.

Flournoy, D. S., T. K. Kirk, and T. L. Highley. 1991. Wood decay by brown-rot fungi: Changes in pore structure and cell wall volume. Holzforschung 45:383-388.

Fonty, G., and F. Chaucheyras-Durand. 2006. Effects and modes of action of live yeasts in the rumen. Biologia (Bratisl.) 61:741-750. https://doi.org/10.2478/s11756-006-0151-4.

Forsberg, C. W., E. Forano, and A. Chesson. 2000. Microbial adherence to the plant cell wall and enzymatic hydrolysis. Pages 79-98 in Ruminant Physiology: Digestion, Metabolism, Growth and Reproduction. P. B. Cronje, ed. CABI Publishing, Wallingford, UK.

Furukawa, K., S. Ichikawa, M. Nigorikawa, T. Sonoki, and Y. Ito. 2014. Enhanced production of reducing sugars from transgenic rice expressing exo-glucanase under the control of a senescenceinducible promoter. Transgenic Res. 23:531-537. https://doi.org/ 10.1007/s11248-014-9786-z.

Gado, H. M., A. Z. M. Salem, P. H. Robinson, and M. Hassan. 2009. Influence of exogenous enzymes on nutrient digestibility, extent of ruminal fermentation as well as milk production and composition in dairy cows. Anim. Feed Sci. Technol. 154:36-46. https://doi .org/10.1016/j.anifeedsci.2009.07.006.

Galyean, M. L., and A. L. Goetsch. 1993. Utilization of forage fiber by ruminants. Pages 33-37 in Forage Cell Wall Structure and Digestibility. H. G. Jung, D. R. Buxton, R. D. Hatfield, and J. Ralph, ed. ASA-CSSA-SSSA, Madison, WI.

Gandi, J., M. T. Holtzapple, A. Ferrer, F. M. Byers, N. D. Turner, M. Nagwani, and S. Chang. 1997. Lime treatment of agricultural residues to improve rumen digestibility. Anim. Feed Sci. Technol. 68:195-211. https://doi.org/10.1016/s0377-8401(97)00050-3.

Gao, Z., T. Mori, and R. Kondo. 2012. The pretreatment of corn stover with Gloeophyllum trabeum KU-41 for enzymatic hydrolysis. Biotechnol. Biofuels 5:28. https://doi.org/10.1186/1754-6834-5-28.

Garrett, W. N., H. G. Walker, G. O. Kohler, A. C. Waiss, R. P. Graham, N. E. East, and M. R. Hart. 1974. Nutritive value of $\mathrm{NaOH}$ and $\mathrm{NH}_{3}$ - treated rice straws. Proc. W. Sect. Am. Soc. Anim. Sci. $25: 317$.

Georgelis, N., N. Nikolaidisa, and D. J. Cosgrove. 2014. Biochemical analysis of expansin-like proteins from microbes. Carbohydr. Polym. 100:17-23. https://doi.org/10.1016/j.carbpol.2013.04.094.

Georgelis, N., A. Tabuchi, N. Nikolaidis, and D. J. Cosgrove. 2011. Structure-function analysis of the bacterial expansin EXLX1. J Biol. Chem. 286:16814-16823. https://doi.org/10.1074/jbc.M111 .225037 .

Giordano, A., L. Zhiqian, S. N. Panter, A. M. Dimech, Y. Shang, H. Wijesinghe, K. Fulgueras, Y. Ran, A. Mouradov, S. Rochfort, N. J. Patron, and G. C. Spangenberg. 2014. Reduced lignin content and altered lignin composition in the warm season forage grass Paspalum dilatatum by down-regulation of a Cinnamoyl CoA reductase gene. Transgenic Res. 23:503-517.

Giraldo, L. A., M. L. Tejido, M. J. Ranilla, S. Ramos, and M. D. Carro. 2008. Influence of direct-fed fibrolytic enzymes on diet digest- ibility and ruminal activity in sheep fed a grass hay-based diet. J. Anim. Sci. 86:1617-1623. https://doi.org/10.2527/jas.2007-0343.

Gligorovski, S., R. Strekowski, S. Barbati, and D. Vione. 2015. Environmental implications of hydroxyl radicals $(\bullet \mathrm{OH})$. Chem. Rev. 115:13051-13092. https://doi.org/10.1021/cr500310b.

Grabber, J. H. 2005. How do lignin composition, structure, and crosslinking affect degradability? A review of cell wall model studies. Crop Sci. 45:820-831. https://doi.org/10.2135/cropsci2004.0191.

Grabber, J. H., J. Ralph, and R. D. Hatfield. 1998. Ferulate cross-links limit the enzymatic degradation of synthetically lignified primary walls of maize. J. Agric. Food Chem. 46:2609-2614. https://doi .org/10.1021/jf9800099.

Grant, R. J., and L. F. Ferraretto. 2018. Silage review: Silage feeding management: Silage characteristics and dairy cow feeding behavior. J. Dairy Sci. 101:4111-4121. https://doi.org/10.3168/jds.2017 -13729 .

Griffith, C. L., G. O. Ribeiro Jr., M. Oba, T. A. McAllister, and K. A. Beauchemin. 2016. Fermentation of ammonia fiber expansion treated and untreated barley straw in a rumen simulation technique using rumen inoculum from cattle with slow versus fast rate of fiber disappearance. Front. Microbiol. 7:1839. https://doi.org/ 10.3389/fmicb.2016.01839.

Guerra, A., R. Mendonça, and A. Ferraz. 2003. Molecular weight distribution of wood components extracted from Pinus taeda biotreated by Ceriporiopsis subvermispora. Enzyme Microb. Technol. 33:12-18. https://doi.org/10.1016/S0141-0229(03)00099-1.

Guo, D., F. Chen, J. Wheeler, J. Winder, S. Selman, M. Peterson, and R. A. Dixon. 2001. Improvement of in-rumen digestibility of alfalfa forage by genetic manipulation of lignin O-methyltransferases. Transgenic Res. 10:457-464.

Hacker, J. B., and D. J. Minson. 1981. The digestibility of plant parts. Herb. Abstr. 51:459-482.

Haddad, S. G., R. J. Grant, and S. D. Kachman. 1998. Effect of wheat straw treated with alkali on ruminal function and lactational performance of dairy cows. J. Dairy Sci. 81:1956-1965. https://doi .org/10.3168/jds.S0022-0302(98)75769-8.

Hall, M. B., and D. R. Mertens. 2017. A 100-year review: Carbohydrates - Characterization, digestion, and utilization. J. Dairy Sci. 100:10078-10093. https://doi.org/10.3168/jds.2017-13311.

Hameleers, A. 1998. The effects of the inclusion of either maize silage, fermented whole crop wheat or urea-treated whole crop wheat in a diet based on a high-quality grass silage on the performance of dairy cows. Grass Forage Sci. 53:157-163. https://doi.org/10 .1046/j.1365-2494.1998.5320157.x.

Harper, M. T., A. Melgar, J. Oh, K. Nedelkov, G. Sanchez, G. W. Roth, and A. N. Hristov. 2018. Inclusion of brown midrib dwarf pearl millet silage in the diet of lactating dairy cows. J. Dairy Sci. 101:5006-5019. https://doi.org/10.3168/jds.2017-14036.

Haque, M. A., K. M. Cho, D. N. Barman, M. K. Kim, and H. D. Yun. 2015. A potential cellulose microfibril swelling enzyme isolated from Bacillus sp. AY8 enhances cellulose hydrolysis. Process Biochem. 50:807-815. https://doi.org/10.1016/j.procbio.2015.02.003.

Harrison, M. D., Z. Zhang, K. Shand, B. F. Chong, J. Nichols, P. Oeller, I. M. O'hara, W. O. S. Doherty, and J. L. Dale. 2014. The combination of plant expressed cellobiohydrolase and low dosages of cellulases for the hydrolysis of sugar cane bagasse. Biotechnol. Biofuels 7:131. https://doi.org/10.1186/s13068-014-0131-9.

Hart, M. R., H. G. Walker Jr., R. P. Graham, P. J. Hanni, A. H. Brown, and G. O. Kohler. 1980. Steam treatment of crop residues for increased ruminant digestibility. I. Effects of process parameters. J. Anim. Sci. 51:402-408. https://doi.org/10.2527/jas1980 $.512402 \mathrm{x}$.

Hatakka, A. 2001. Biopolymer, biology, chemistry, biotechnology application. Pages 129-180 in Lignin, Humic Substance and Coal. Wiley-Blackwell, Weinheim, Germany.

Hatfield, R. D., H. J. G. Jung, G. Broderick, and T. C. Jenkins. 2007. Nutritional chemistry of forages. Pages 467-485 in Forages: The Science of Grassland Agriculture. R. F. Barnes, C. J. Nelson, K. J. Moore, and M. Collins, ed. Blackwell Publishing, Ames, IA.

Hatfield, R. D., J. Ralph, and J. H. Grabber. 1999a. Cell wall structural foundations: Molecular basis for improving forage digest- 
ibilities. Crop Sci. 39:27-37. https://doi.org/10.2135/cropsci1999 $.0011183 x 003900010005 x$.

Hatfield, R. D., J. Ralph, and J. H. Grabber. 1999b. Review: Cell wall cross-linking by ferulates and diferulates in grasses. J. Sci. Food Agric. 79:403-407. https://doi.org/10.1002/(sici)1097 -0010(19990301)79:3<403:aid-jsfa263>3.3.co;2-s.

Hatfield, R. D., D. M. Rancour, and J. M. Marita. 2017. Grass cell walls: A story of cross-linking. Front. Plant Sci. 7:2056. https://doi .org/10.3389/fpls.2016.02056.

Hedges, J. I., R. A. Blanchette, K. Weliky, and A. H. Devol. 1988. Effects of fungal degradation on the $\mathrm{CuO}$ oxidation products of lignin: A controlled laboratory study. Geochim. Cosmochim. Acta 52:2717-2726. https://doi.org/10.1016/0016-7037(88)90040-3.

Henderson, N. 1993. Silage additives. Anim. Feed Sci. Technol. 45:3556. https://doi.org/10.1016/0377-8401(93)90070-z.

Highley, T. L. 1991. Processes of wood decay and deterioration. Pages 227-230 in Biodeterioration Research 4: Mycotoxins, Wood Decay, Plant Stress, Biocorrosion, and General Biodeterioration. 4th ed. Plenum Press, New York, NY.

Holt, M. S., J. S. Eun, C. R. Thacker, A. J. Young, X. Dai, and K. E. Nestor. 2013. Effects of feeding brown midrib corn silage with a high dietary concentration of alfalfa hay on lactational performance of Holstein dairy cows for the first 180 days of lactation. J. Dairy Sci. 96:515-523. https://doi.org/10.3168/jds.2012-5856.

Horton, G. M. J., and G. M. Steacy. 1979. Effect of anhydrous ammonia treatment on the intake and digestibility of cereal straws by steers. J. Anim. Sci. 48:1239-1249. https://doi.org/10.2527/ jas1979.4851239x.

Hristov, A. N., T. A. McAllister, and K. J. Cheng. 1998. Effect of dietary or abomasal supplementation of exogenous polysaccharidedegrading enzymes on rumen fermentation and nutrient digestibility. J. Anim. Sci. 76:3146-3156. https://doi.org/10.1016/s0168 -1656(03)00123-8.

Hristov, A. N., T. A. McAllister, and K. J. Cheng. 2000. Intraruminal supplementation with increasing levels of exogenous polysaccharide-degrading enzymes: effects on nutrient digestion in cattle fed a barley grain diet. J. Anim. Sci. 78:477-487. https://doi.org/10 $.2527 / 2000.782477 \mathrm{x}$.

Ishizawa, C. I., M. F. Davis, D. F. Schell, and D. K. Hohnson. 2007. Porosity and its effect on the digestibility of dilute sulfuric acid pretreated corn stover. J. Agric. Food Chem. 55:2575-2581. https: //doi.org/10.1021/jf062131a.

Itoh, H., M. Wada, Y. Honda, M. Kuwahara, and T. Watanabe. 2003. Bioorganosolve pretreatments for simultaneous saccharification and fermentation of beech wood by ethanolysis and white rot fungi. J. Biotechnol. 103:273-280. https://doi.org/10.1016/s0168 $-1656(03) 00123-8$.

Jackson, B., and Fl. Dessau. 1961. Liver tumors in rats fed acetamide. Lab. Invest. 10:909-923.

Jackson, M. G. 1977. Review article: The alkali treatment of straws. Anim. Feed Sci. Technol. 2:105-130. https://doi.org/10.1016/0377 -8401(77)90013-x.

Jacobs, J. L., J. E. Cook, and A. B. Mcallan. 1991. Enzymes as silage additives 2 . The effect of grass dry matter content on silage quality and performance in sheep. Grass Forage Sci. 46:191-199. https:// doi.org/10.1111/j.1365-2494.1991.tb02222.x.

Jami, E., N. Shterzer, E. Yosef, M. Nikbachat, J. Miron, and I. Mizrahi. 2014. Effects of including $\mathrm{NaOH}$-treated corn straw as a substitute for wheat hay in the ration of lactating cows on performance, digestibility, and rumen microbial profile. J. Dairy Sci. 97:1623-1633. https://doi.org/10.3168/jds.2013-7192.

Jiang, Y., I. M. Ogunade, K. G. Arriola, M. Qi, D. Vyas, C. R. Staples, and A. T. Adesogan. 2017a. Effects of the dose and viability of Saccharomyces cerevisiae. 2. Ruminal fermentation, performance of lactating dairy cows, and correlations between ruminal bacteria abundance and performance measures. J. Dairy Sci. 100:81028118. https://doi.org/10.3168/jds.2016-12371.

Jiang, Y., I. M. Ogunade, S. Qi, T. J. Hackmann, C. R. Staples, and A. T. Adesogan. 2017b. Effects of the dose and viability of Saccharomyces cerevisiae. 1. Diversity of ruminal microbes as analyzed by Illumina MiSeq sequencing and quantitative PCR. J. Dairy Sci. 100:325-342. https://doi.org/10.3168/jds.2016-11263.

Johnson, L., J. H. Harrison, C. Hunt, K. Shinners, C. G. Doggett, and D. Sapienza. 1999. Nutritive value of corn silage as affected by maturity and mechanical processing: A contemporary review. J. Dairy Sci. 82:2813-2825. https://doi.org/10.3168/jds.S0022 -0302(99)75540-2.

Jouany, J. P., F. Mathieu, J. Sénaud, J. Bohatier, G. Bertin, and M. Mercier. 1998. The effect of Saccharomyces cerevisiae and Aspergillus oryzae on the digestion of the cell wall fraction of a mixed diet in defaunated and refaunated sheep rumen. Reprod. Nutr. Dev. 38:401-416. https://doi.org/10.1051/rnd:19980405.

Ju, X., M. Engelhard, and X. Zhang. 2013. An advanced understanding of the specific effects of xylan and surface lignin contents on enzymatic hydrolysis of lignocellulosic biomass. Bioresour. Technol. 132:137-145. https://doi.org/10.1016/j.biortech.2013.01.049.

Jung, H., and D. Deetz. 1993. Cell wall lignification and degradability. Pages $315-340$ in Forage Cell Wall Structure and Digestibility. H. G. Jung, D. R. Buxton, R. D. Hatfield, and J. Ralph, ed. ASA, CSSA, and SSSA, Madison, WI.

Jung, H. G., and M. S. Allen. 1995. Characteristics of plant cell walls affecting intake and digestibility of forages by ruminants. J. Anim. Sci. 73:2774-2790. https://doi.org/10.2527/1995.7392774x.

Jung, H. G., D. R. Mertens, and R. L. Phillips. 2011. Effect of reduced ferulate-mediated lignin/arabinoxylan cross-linking in corn silage on feed intake, digestibility, and milk production. J. Dairy Sci. 94:5124-5137. https://doi.org/10.3168/jds.2011-4495.

Jung, H. G., and R. L. Phillips. 2010. Putative seedling ferulate ester (sfe) maize mutant: Morphology, biomass yield, and stover cell wall composition and rumen degradability. Crop Sci. 50:403-418. https://doi.org/10.2135/cropsci2009.04.0191.

Jung, H. J. G. 2012. Forage digestibility: The intersection of cell wall lignification and plant tissue anatomy. Pages $162-173$ in Proc. 23rd Annual Florida Ruminant Nutrition Symposium, Gainesville, FL.

Jung, H. J. G., and M. D. Casler. 1991. Relationship of lignin and esterified phenolics to fermentation of smooth bromegrass fibre. Anim. Feed Sci. Technol. 32:63-68. https://doi.org/10.1016/0377 -8401(91)90010-p.

Kaffenberger, J. T., and J. S. Schilling. 2015. Comparing lignocellulose physiochemistry after decomposition by brown rot fungi with distinct evolutionary origins. Environ. Microbiol. 17:4885-4897. https://doi.org/10.1111/1462-2920.12615.

Kang, K., S. Wang, G. Lai, G. Liu, and M. Xing. 2013. Characterization of a novel swollenin from Penicillium oxalicum in facilitating enzymatic saccharification of cellulose. BMC Biotechnol. 13:42. https://doi.org/10.1186/1472-6750-13-42.

Kang, T. W., A. T. Adesogan, S. C. Kim, and S. S. Lee. 2009. Effects of an esterase-producing inoculant on fermentation, aerobic stability, and neutral detergent fiber digestibility of corn silage. J. Dairy Sci. 92:732-738. https://doi.org/10.3168/jds.2007-0780.

Karunanandaa, K., and G. A. Varga. 1996. Colonization of rice straw by white-rot fungi (Cyathus stercoreus): Effect on ruminal fermentation pattern, nitrogen metabolism, and fiber utilization during continuous culture. Anim. Feed Sci. Technol. 61:1-16. https://doi .org/10.1016/0377-401(96)00958-3.

Keady, T. W., and J. J. Murphy. 1996. Effects of inoculant treatment on ryegrass silage fermentation, digestibility, rumen fermentation, intake and performance of lactating dairy cattle. Grass Forage Sci. 51:232-241. https://doi.org/10.1111/j.1365-2494.1996.tb02058.x.

Kendall, C., C. Leonardi, P. C. Hoffman, and D. K. Combs. 2009. Intake and milk production of cows fed diets that differed in dietary neutral detergent fiber and neutral detergent fiber digestibility. J. Dairy Sci. 92:313-323.

Kennedy, P. M., and P. Doyle. 1993. Particle-size reduction by ruminant-effects of cell wall composition. Pages 499-534 in Forage Cell Wall Structure and Digestibility. H. G. Jung, D. R. Buxton, R. D. Hatfield, and J. Ralph, ed. ASA, CSSA, and SSSA, Madison, WI.

Kennedy, S. J. 1990. Comparison of the fermentation quality and nutritive value of sulphuric and formic acid-treated silages fed to beef cattle. Grass Forage Sci. 45:17-28. https://doi.org/10.1111/j.1365 -2494.1990.tb02178.x. 
Kerem, Z., K. A. Jensen, and K. E. Hammel. 1999. Biodegradative mechanism of the brown rot basidiomycete Gloeophyllum trabeum: Evidence for an extracellular hydroquinone-driven fenton reaction. FEBS Lett. 446:49-54. https://doi.org/10.1016/s0014 -5793(99)00180-5.

Kersten, P. J., M. Tien, B. Kalyanaraman, and T. K. Kirk. 1985. The ligninase of Phanerochaete chrysosporium generates cation radicals from methoxybenzenes. J. Biol. Chem. 260:2609-2612.

Khafipour, E., D. O. Krause, and J. C. Plazier. 2009. Alfalfa pelletinduced subacute ruminal acidosis in dairy cows increases bacterial endotoxin in the rumen without causing inflammation. J. Dairy Sci. 92:1712-1724. https://doi.org/10.3168/jds.2008-1656.

Kim, E. S., H. J. Lee, W. G. Bang, I. G. Choi, and K. H. Kim. 2009 Functional characterization of a bacterial expansin from Bacillus subtilis for enhanced enzymatic hydrolysis of cellulose. Biotechnol. Bioeng. 102:1342-1353. https://doi.org/10.1002/bit.22193.

Kim, I. J., H. J. Ko, T. W. Kim, K. H. Nam, I. G. Choi, and K. H. Kim. 2013. Binding characteristics of a bacterial expansin (BsEXLX1) for various types of pretreated lignocellulose. Appl. Microbiol. Biotechnol. 97:5381-5388. https://doi.org/10.1007/s00253 $-012-4412-6$

Kleman-Leyer, K., E. Agosin, A. H. Conner, and T. K. Kirk. 1992. Cchanges in molecular size distribution of cellulose during attack by white rot and brown rot fungi. Appl. Environ. Microbiol. $58: 1266-1270$

Klopfenstein, T. J., V. E. Krause, M. J. Jones, and W. Woods. 1972. Chemical treatment of low quality roughages. J. Anim. Sci. 35:418-422. https://doi.org/10.2527/jas1972.352418x.

Krueger, N. A. 2006. Effect of fibrolytic enzymes on the nutritive value of tropical forages and performance of beef steers. $\mathrm{PhD}$ Diss. Department of Animal Science, University of Florida, Gainesville.

Krueger, N. A., A. T. Adesogan, C. R. Staples, W. K. Krueger, D. B. Dean, and R. C. Littell. 2008a. The potential to increase digestibility of tropical grasses with a fungal, ferulic acid esterase enzyme preparation. Anim. Feed Sci. Technol. 145:95-108. https:/ /doi.org/10.1016/j.anifeedsci.2007.05.042.

Krueger, N. A., A. T. Adesogan, C. R. Staples, W. K. Krueger, S. C. Kim, R. C. Littell, and L. E. Sollenberger. 2008b. Effect of method of applying fibrolytic enzymes or ammonia to Bermudagrass hay on feed intake, digestion, and growth of beef steers. J. Anim. Sci. 86:882-889. https://doi.org/10.2527/jas.2006-717.

Kumar, K. A., and D. J. Adrews. 1993. Genetics of qualitative traits in pearl millet: A review. Crop Sci. 33:1-20. https://doi.org/10.2135/ cropsci1993.0011183x003300010001x.

Kumar, R., and C. E. Wyman. 2009. Access of cellulase to cellulose and lignin for poplar solids produced by leading pretreatment technologies. Biotechnol. Prog. 25:807-819. https://doi.org/ $10.1002 /$ btpr. 153

Kung, L., and J. T. Huber. 1983. Performance of high producing cows in early lactation fed protein of varying amounts, sources, and degradability. J. Dairy Sci. 66:227-234. https://doi.org/10.3168/ jds.S0022-0302(83)81781-0.

Kung, L. Jr., C. C. Taylor, M. P. Lynch, and J. M. Neylon. 2003. The effect of treating alfalfa with Lactobacillus buchneri 40788 on silage fermentation, aerobic stability, and nutritive value for lactating dairy cows. J. Dairy Sci. 86:336-343.

Leaver, J. D., and J. Hill. 1995. The performance of dairy cows offered ensiled whole-crop wheat, urea-treated whole-crop wheat or sodium hydroxide-treated wheat grain and wheat straw in a mixture with grass silage. Anim. Sci. 61:481-489. https://doi.org/10.1017/ S1357729800014041.

Lechtenberg, V. L., D. A. Holt, and H. W. Youngberg. 1971. Diurnal variation in nonstructural carbohydrates, in vitro digestibility, and leaf to stem ratio of alfalfa. Agron. J. 63:719-724.

Lee, H. J., I. Jung, J. F. Kim, I. Choi, and K. Heon. 2013. An expansin from the marine bacterium Hahella chejuensis acts synergistically with xylanase and enhances xylan hydrolysis. Bioresour. Technol. 149:516-519. https://doi.org/10.1016/j.biortech.2013.09.086.

Leonardi, C., and L. E. Armentano. 2003. Effect of quantity, quality and length of alfalfa hay on selective consumption by dairy cows. J. Dairy Sci. 86:557-564. https://doi.org/10.3168/jds.S0022 -0302(03)73634-0.

Li, Z., Z. Li, and D. Combs. 2015. Effect of reduced lignin alfalfa on forage quality at three harvest intervals. J. Dairy Sci. 98(E-suppl 2):675. (Abstr.)

Lila, Z. A., N. Mohammed, T. Yasui, Y. Kurokawa, S. Kanda, and H. Itabashi. 2004. Effects of a twin strain of Saccharomyces cerevisiae live cells on mixed ruminal microorganism fermentation in vitro. J. Anim. Sci. 82:1847-1854.

Liu, X., C. Liu, Y. Ma, J. Hong, and M. Zhang. 2014. Heterologous expression and functional characterization of a novel cellulosedisruptive protein Le EXP2 from Lycopersicum esculentum. J. Biotechnol. 186:148-155. https://doi.org/10.1016/j.jbiotec.2014 .07 .013 .

Liu, J. X., and E. R. Orskov. 2000. Cellulase treatment of untreated and steam pre-treated rice straw - effect on in vitro fermentation characteristics. Anim. Feed Sci. Technol. 88:189-200. https://doi .org/10.1016/s0377-8401(00)00218-2.

Liu, J. X., E. R. Orskov, and X. B. Chen. 1999. Optimization of steam treatment as a method for upgrading rice straw as feeds. Anim. Feed Sci. Technol. 76:345-357. https://doi.org/10.1016/s0377 -8401(98)00196-5.

Liu, X., Y. Ma, and M. Zhang. 2015. Research advances in expansins and expansion-like proteins involved in lignocellulose degradation. Biotechnol. Lett. 37:1541-1551. https://doi.org/10.1007/s10529 $-015-1842-0$.

Lopes, F., K. Ruh, and D. K. Combs. 2015. Validation of an approach to predict total-tract fiber digestibility using a standardized in vitro technique for different diets fed to high-producing dairy cows. J. Dairy Sci. 98:2596-2602. https://doi.org/10.3168/jds.2014-8665.

Lorenzo, B. F., and P. O'Kiely. 2008. Alternatives to formic acid as a grass silage additive under two contrasting ensilabilty conditions. Ir. J. Agric. Food Res. 47:135-149.

Lynch, H. A., and S. A. Martin. 2002. Effects of Saccharomyces cerevisiae culture and Saccharomyces cerevisiae live cells on in vitro mixed ruminal microorganism fermentation. J. Dairy Sci. 85:26032608. https://doi.org/10.3168/jds.S0022-0302(02)74345-2.

Lynch, J. P., J. Baah, and K. A. Beauchemin. 2015. Conservation, fiber digestibility, and nutritive value of corn harvested at 2 cutting heights and ensiled with fibrolytic enzymes, either alone or with a ferulic acid esterase-producing inoculant. J. Dairy Sci. 98:12141224. https://doi.org/10.3168/jds.2014-8768.

Lynch, J. P., J. Lin, E. C. Lara, J. Baah, and K. A. Beauchemin. 2014 The effect of exogenous fibrolytic enzymes and a ferulic acid esterase-producing inoculant on the fibre degradability, chemical composition and conservation characteristics of alfalfa silage. Anim. Feed Sci. Technol. 193:21-31. https://doi.org/10.1016/j.anifeedsci .2014.03.013.

Mani, S., L. G. Tabil, and S. Sokhansanj. 2006. Effects of compressive force, particle size and moisture content on mechanical properties of biomass pellets from grasses. Biomass Bioenergy 30:648-654. https://doi.org/10.1016/j.biombioe.2005.01.004.

Mapato, C., M. Wanapat, and A. Cherdthong. 2010. Effects of urea treatment of straw and dietary level of vegetable oil on lactating dairy cows. Trop. Anim. Health Prod. 42:1635-1642. https://doi .org/10.1007/s11250-010-9613-3.

Marden, J. P., C. Julien, V. Monteils, E. Auclair, R. Moncoulon, and C. Bayourthe. 2008. How does live yeast differ from sodium bicarbonate to stabilize ruminal $\mathrm{pH}$ in high-yielding dairy cows? J. Dairy Sci. 91:3528-3535. https://doi.org/10.3168/jds.2007-0889.

Martin, N. P., M. P. Russelle, J. M. Powell, C. J. Sniffen, S. I. Smith J. M. Tricarico, and R. J. Grant. 2017. Invited review: Sustainable forage and grain crop production for the US dairy industry. J. Dairy Sci. 100:9479-9494. https://doi.org/10.3168/jds.2017-13080.

Martinez, A. T., J. Rencoret, L. Nieto, J. Jiménez-Barbero, A. Gutiérrez, and J. C. delRío. 2011. Selective lignin and polysaccharide removal innatural fungal decay of wood as evidenced by in situ structural analyses. Environ. Microbiol. 13:96-107. https://doi .org/10.1111/j.1462-2920.2010.02312.x.

Martinez, A. T., M. Speranza, F. J. Ruiz-Duenas, P. Ferreira, S. Camarero, F. Guillen, M. J. Martinez, A. Gutierrez, and J. C. del 
Rio. 2005. Biodegradation of lignocellulosics: microbial, chemical, and enzymatic aspects of the fungal attack of lignin. Int. Microbiol. 8:195-204.

Mathieu, Y., E. Gelhaye, S. Dumarçay, P. Gérardin, L. Harvengt, and M. Buée. 2013. Selection and validation of enzymatic activities as functional markers in wood biotechnology and fungal ecology. J. Microbiol. Methods 92:157-163. https://doi.org/10.1016/j.mimet .2012.11.017.

Mayne, C. S. 1993. The effect of formic acid, sulfuric acid and a bacterial inoculant on silage fermentation and the food intake and milk production of lactating dairy cows. Anim. Sci. 56:29-42. https:// doi.org/10.1017/S0003356100006139.

McAllister, T. A., A. N. Hristov, K. A. Beauchemin, L. M. Rode, and K. J. Cheng. 2001. Enzymes in ruminant diets. Pages 273-298 in Enzymes in Farm Animal Nutrition. M. Bedford and G. Partridge, ed. CABI Publishing, Oxon, UK. https://doi.org/10.1079/ 9780851993935.0273 .

Meale, S. J., K. A. Beauchemin, A. N. Hristov, A. V. Chaves, and T. A. McAllister. 2014. Invited review: opportunities and challenges in using exogenous enzymes to improve ruminant production. J. Anim. Sci. 92:427-442. https://doi.org/10.2527/jas.2013-6869.

Mertens, D. R. 1987. Predicting intake and digestibility using mathematical models of ruminal function. J. Anim. Sci. 64:1548-1558. https://doi.org/10.2527/jas1987.6451548x.

Mertens, D. R. 1997. Creating a system for meeting the fiber requirements of dairy cows. J. Dairy Sci. 80:1463-1481. https://doi.org/ 10.3168/jds.S0022-0302(97)76075-2.

Mertens, D. R, and M. McCaslin., 2008. Evaluation of alfalfa hays with down-regulated lignin biosynthesis. J. Dairy Sci. 91(E-suppl. 1):170. (Abstr.)

Miller, L. A., J. M. Moorby, D. R. Davies, M. O. Humphreys, N. D. Scollan, J. C. MacRae, and M. K. Theodorou. 2001. Increased concentration of water-soluble carbohydrate in perennial ryegrass (Lolium perenne L.): Milk production from late-lactation dairy cows. Grass Forage Sci. 56:383-394.

Mor, P., B. Bals, S. Kumar, N. Tyagi, J. K. Reen, B. Tyagi, P. K. Choudhury, and A. K. Tyagi. 2019. Influence of replacing concentrate mixture with AFEX pellets on rumen fermentation, blood profile and acetamide content in the rumen of crossbred (Alpine $\times$ Beetle) female goats. Small Rumin. Res. 170:109-115.

Mor, P., B. Bals, A. Tyagi, F. Teymouri, N. Tyagi, S. Kumar, V. Bringi, and M. VandeHaar. 2018. Effect of ammonia fiber expansion on the available energy content of wheat straw fed to lactating cattle and buffalo in India. J. Dairy Sci. 101:7990-8003. https:// doi.org/10.3168/jds.2018-14584.

Moreno, A. D., D. Ibarra, J. L. Fernández, and M. Ballesteros. 2012. Different laccase detoxification strategies for ethanol production from lignocellulosic biomass by the thermotolerant yeast Kluyveromyces marxianus CECT 10875. Bioresour. Technol. 106:101-109. https://doi.org/10.1016/j.biortech.2011.11.108.

Morgavi, D. P., K. A. Beauchemin, V. L. Nsereko, L. M. Rode, A. D. Iwaasa, W. Z. Yang, T. A. McAllister, and Y. Yang. 2000. Synergy between ruminal fibrolytic enzymes and enzymes from Trichoderma longibrachiatum. J. Dairy Sci. 83:1310-1321. https:// doi.org/10.3168/jds.S0022-0302(00)74997-6.

Mottet, A., C. de Haan, A. Falcucci, G. Tempio, C. Opio, and P. Gerber. 2017. Livestock: On our plates or eating at our table? A new analysis of the feed/food debate. Glob. Food Secur. 14:1-8.

Muck, R. E., and K. K. Bolsen. 1991. Silage preservation and silage additive products. Page 105 in Field Guide for Hay and Silage Management in North America. K. K. Bolsen, J. E. Baylor, and M. E. McCullough, ed. Natl. Feed Ingred. Assoc., West Des Moines, IA.

Muck, R. E., E. M. G. Nadeau, T. A. McAllister, F. E. ContrerasGovea, M. C. Santos, and L. Kung Jr.. 2018. Silage review: Recent advances and future uses of silage additives. J. Dairy Sci. 101:3980-4000. https://doi.org/10.3168/jds.2017-13839.

Muller, L., W. Langseth, E. Solheim, and T. Sivertsen. 1998. Ammoniated forage poisoning: Isolation and characterization of alkylsubstituted imidazole in ammoniated forage and in milk. J. Agric. Food Chem. 46:3172-3177. https://doi.org/10.1021/jf9710239.
Mullins, C. R., L. K. Mamedova, A. J. Carpenter, Y. Ying, M. S. Allen. I. Yoon, and B. J. Bradford. 2013. Analysis of rumen microbial populations in lactating dairy cattle fed diets varying in carbohydrate profiles and Saccharomyces cerevisiae fermentation product. J. Dairy Sci. 96:5872-5881. https://doi.org/10.3168/jds .2013-6775.

Mustafa, A. F., F. Hassanat, and P. Seguin. 2004. Chemical composition and in situ ruminal nutrient degradability of normal and brown midrib forage pearl millet grown in southwestern Québec. Can. J. Anim. Sci. 84:737-740. https://doi.org/10.4141/A04-030.

Nagel, S. A., and G. A. Broderick. 1992. Effect of formic acid or formaldehyde treatment of alfalfa silage on nutrient utilization by dairy cows. J. Dairy Sci. 75:140-154. https://doi.org/10.3168/jds.S0022 -0302(92)77748-0.

Nayan, N., A. S. M. Sonnenberg, W. H. Hendriks, and J. W. Cone. 2018. Screening of white-rot fungi for bioprocessing of wheat straw into ruminant feed. J. Appl. Microbiol. https://doi.org/10.1111/ jam. 13894

Newbold, C. J., F. M. McIntosh, and R. J. Wallace. 1998. Changes in the microbial population of a rumen-simulating fermenter in response to yeast. Can. J. Anim. Sci. 78:241-244. https://doi.org/ 10.4141/a97-086.

Newbold, C. J., R. J. Wallace, and F. M. McIntosh. 1996. Mode of action of the yeast Saccharomyces cerevisiae as a feed additive for ruminants. Br. J. Nutr. 76:249-261. https://doi.org/10.1079/ bjn19960029.

NRC. 2001. Nutrient Requirements of Dairy Cattle. 7th ed. Natl. Acad. Press, Washington, DC.

Nsereko, V. L., K. A. Beauchemin, D. P. Morgavi, L. M. Rode, A. F. Furtado, T. A. McAllister, D. Iwaasa, W. Z. Yang, and Y. Wang. 2002. Effect of a fibrolytic enzyme preparation from Trichoderma longibrachiatum on the rumen microbial population of dairy cows. Can. J. Microbiol. 48:14-20. https://doi.org/10.1139/w01-131.

Nsereko, V. L., D. P. Morgavi, L. M. Rode, K. A. Beauchemin, and T. A. McAllister. 2000. Effects of fungal enzyme preparations on hydrolysis and subsequent degradation of alfalfa hay fiber by mixed rumen microorganisms in vitro. Anim. Feed Sci. Technol. 88:153170. https://doi.org/10.1016/S0377-8401(00)00225-X.

Nsereko, V. L., B. K. Smiley, W. M. Rutherford, A. Spielbauer, K. J. Forrester, G. H. Hettinger, E. K. Harman, and B. R. Harman. 2008. Influence of inoculating forage with lactic acid bacterial strains that produce ferulate esterase on ensilage and ruminal degradation of fiber. Anim. Feed Sci. Technol. 145:122-135. https:// doi.org/10.1016/j.anifeedsci.2007.06.039.

Nurjana, D. J., S. Suharti, and Surhayadi.. 2016. Improvement of napier grass silage nutritive value by using inoculant and crude enzymes from Trichoderma reesei and its effect on in vitro rumen fermentation. Media Peternakan 39:46-52. https://doi.org/10 $.5398 /$ medpet.2016.39.1.46.

Oba, M., and M. S. Allen. 1999. Evaluation of the importance of the digestibility of neutral detergent fiber from forage: Effects on dry matter intake and milk yield of dairy cows. J. Dairy Sci. 82:589596. https://doi.org/10.3168/jds.S0022-0302(99)75271-9.

Oba, M., and M. S. Allen. 2000. Effects of brown midrib 3 mutation in corn silage on productivity of dairy cows fed two concentrations of dietary neutral detergent fiber: 3. Digestibility and microbial efficiency. J. Dairy Sci. 83:1350-1358. https://doi.org/10.3168/jds .S0022-0302(00)75002-8.

Öhgren, K., R. Bura, J. Saddler, and G. Zacchi. 2007. Effect of hemicellulose and lignin removal on enzymatic hydrolysis of steam pretreated corn stover. Bioresour. Technol. 98:2503-2510. https://doi .org/10.1016/j.biortech.2006.09.003.

Oji, U. I., and D. N. Mowat. 1978. Nutritive value of steam-treated corn stover. Can. J. Anim. Sci. 58:177-181. https://doi.org/10 .4141/cjas78-025.

O'Kiely, P., A. V. Flynn, and D. B. R. Poole. 1989. Sulfuric acid as a silage preservative. 1 . Silage preservation, animal performance and copper status. Isr. J. Agric. Res. 28:1-9.

Oliveira, A. S., Z. G. Weinberg, I. M. Ogunade, A. A. P. Cervantes, K. G. Arriola, Y. Jiang, D. H. Kim, X. Li, M. C. M. Goncalves, D. Vyas, and A. T. Adesogan. 2017. Meta-analysis of effects of inocu- 
lation with homofermentative and facultative heterofermentative lactic acid bacteria on silage fermentation, aerobic stability, and the performance of dairy cows. J. Dairy Sci. 100:4587-4603. https: //doi.org/10.3168/jds.2016-11815.

Oliver, A. L., J. O'Rear, J. F. Pedersen, and R. J. Grant. 2004. Comparison of brown midrib- 6 and -18 forage sorghum with conventional sorghum and corn silage in diets of lactating dairy cows. J. Dairy Sci. 87:637-644. https://doi.org/10.3168/jds.S0022 -0302(04)73206-3.

Ouellet, D. R., and J. Chiquette. 2016. Effect of dietary metabolizable protein level and live yeasts on ruminal fermentation and nitrogen utilization in lactating dairy cows on a high red clover silage diet. Anim. Feed Sci. Technol. 220:73-82. https://doi.org/10.1016/ j.anifeedsci.2016.07.006.

Paul, S. S., D. N. Kamra, V. R. Sastry, N. P. Sahu, and N. Agarwal. 2004. Effect of anaerobic fungi on in vitro feed digestion by mixed rumen microflora of buffalo. Reprod. Nutr. Dev. 44:313-319.

Pech-Cervantes, A. A., C. F. Gonzalez, I. M. Ogunade, D. H. Kim, A. S. Oliveira, Y. Jiang, D. Vyas, and A. T. Adesogan. 2017a. Bacterial expansins: A novel approach to improve efficacy of exogenous fibrolytic enzymes. J. Dairy. Sci. 100(E. Suppl. 2):164. (Abstr.)

Pech-Cervantes, A. A., Y. Jiang, F. X. Amaro, D. H. Kim, K. G. Arriola, M. Flores-Tensos, C. F. Gonzalez, L. Ferraretto, D. Vyas, and A. T. Adesogan. 2018. Effects of a recombinant bacterial expansin and an exogenous fibrolytic enzyme on preingestive fiber hydrolysis, fermentation and digestibility of corn silage. J. Dairy Sci. 101(E. Suppl. 1):354. (Abstr.)

Pech-Cervantes, A. A., I. M. Ogunade, D. H. Kim, F. X. Amaro, Y. Jiang, K. G. Arriola, C. F. Gonzalez, D. Vyas, and A. T. Adesogan. 2017b. Effect of a recombinant bacterial expansin (BsEXLX1) and fibrolytic enzymes on in vitro digestibility and preingestive hydrolysis of bermudagrass silage. J. Dairy. Sci. 100(E. Suppl. 2):164-165. (Abstr.)

Pedersen, J. F., K. P. Vogel, and D. L. Funnell. 2005. Impact of reduced lignin on plant fitness. Crop Sci. 45:812-819. https://doi .org/10.2135/cropsci2004.0155.

Pelletier, S., G. F. Tremblay, G. Bélanger, A. Bertrand, Y. Castonguay, D. Pageau, and R. Drapeau. 2010. Forage nonstructural carbohydrates and nutritive value as affected by time of cutting and species. Agron. J. 102:1388-1398.

Peyraud, J. L., E. A. Comeron, M. H. Wade, and G. Lemaire. 1996. The effect of daily herbage allowance, herbage mass and animal factors upon herbage intake by grazing dairy cows. Ann. Zootech. 45:201-217.

Pinloche, E., N. McEwan, J.-P. Marden, C. Bayourthe, E. Auclair, and C. J. Newbold. 2013. The effects of a probiotic yeast on the bacterial diversity and population structure in the rumen of cattle. PLoS One 8:e67824. https://doi.org/10.1371/journal.pone.0067824.

Plata, F. P., and J. R. Bárcena-Gama. 1994. Effect of a yeast culture (Saccharomyces cerevisiae) on neutral detergent fiber digestion in steers fed oat straw based diets. Anim. Feed Sci. Technol. 49:203210. https://doi.org/10.1016/0377-8401(94)90046-9.

Pond, K. R., W. C. Ellis, and D. E. Akin. 1984. Ingestive mastication and fragmentation of forages. J. Anim. Sci. 58:1567-1574.

Poore, J., and T. Nemecek. 2018. Reducing food's environmental impacts through producers and consumers. Science 360:987-992. https://doi.org/10.1126/science.aaq0216.

Popp, J. L., B. Kalyanaraman, and T. K. Kirk. 1990. Lignin peroxidase oxidation of $\mathrm{Mn} 2+$ in the presence of veratryl alcohol, malonic or oxalic acid, and oxygen. Biochemistry 29:10475-10480.

Poppy, G. D., A. R. Rabiee, I. J. Lean, W. K. Sanchez, K. L. Dorton, and P. S. Morley. 2012. A meta-analysis of the effects of feeding yeast culture produced by anaerobic fermentation of Saccharomyces cerevisiae on milk production of lactating dairy cows. J. Dairy Sci. 95:6027-6041. https://doi.org/10.3168/jds.2012-5577.

Porter, K. S., J. D. Axtell, V. L. Lechtenberg, and V. F. Colenbrander. 1978. Phenotype, fiber composition, and in vitro dry matter disappearance of chemically induced brown midrib (bmr) mutants of sorghum. Crop Sci. 18:205-208. https://doi.org/10.2135/ cropsci1978.0011183x001800020002x.
Prasad, R. D. D., M. R. Reddy, and G. V. N. Reddy. 1998. Effect of feeding baled and stacked urea treated rice straw on the performance of crossbred cows. Anim. Feed Sci. Technol. 73:347-352. https://doi.org/10.1016/S0377-8401(98)00140-0.

Queiroz, O. C. M., S. C. Kim, and A. T. Adesogan. 2012. Effect of treatment with a mixture of bacteria and fibrolytic enzymes on the quality and safety of corn silage infested with different levels of rust. J. Dairy Sci. 95:5285-5291. https://doi.org/10.3168/jds $.2012-5431$.

Quiroz-Castañeda, R. E., C. Martínez-Anaya, L. I. Cuervo-Soto, L. Segovia, and J. L. Folch-Mallol. 2011. Loosenin, a novel protein with cellulose-disrupting activity from Bjerkandera adusta. Microb. Cell Fact. 10:8. https://doi.org/10.1186/1475-2859-10-8.

Ransom, C., V. Balan, G. Biswas, B. Dale, E. Crockett, and M. Sticklen. 2007. Heterologous Acidothermus cellulolyticus $1,4-\beta$-endoglucanase E1 produced within the corn biomass converts corn stover into glucose. Appl. Biochem. Biotechnol. 137140:207-219. https://doi.org/10.1007/s12010-007-9053-3.

Ribeiro, G. O., R. J. Gruninger, A. Badhan, and T. A. McAllister. 2018. Mining the rumen for fibrolytic feed enzymes. Anim. Front. 6:20-26. https://doi.org/10.2527/af.2016-0019.

Romero, J. J., Z. X. Ma, C. F. Gonzalez, and A. T. Adesogan. 2015c. Effect of adding cofactors to exogenous fibrolytic enzymes on preingestive hydrolysis, in vitro digestibility and fermentation of bermudagrass haylage. J. Dairy Sci. 98:4659-4672. https://doi.org/10 $.3168 /$ jds.2014-8849.

Romero, J. J., E. G. Macias, Z. X. Ma, R. M. Martins, C. R. Staples, K. A. Beauchemin, and A. T. Adesogan. 2016. Improving the performance of dairy cattle with a xylanase-rich exogenous enzyme preparation. J. Dairy Sci. 99:3486-3496. https://doi.org/10.3168/ jds.2015-10082.

Romero, J. J., M. A. Zarate, and A. T. Adesogan. 2015b. Effect of the dose of exogenous fibrolytic enzyme preparations on pre-ingestive fiber hydrolysis and in vitro digestibility of bermudagrass haylage. J. Dairy Sci. 98:406-417. https://doi.org/10.3168/jds.2014-8285.

Romero, J. J., M. A. Zarate, K. G. Arriola, C. F. Gonzalez, C. SilvaSanchez, C. R. Staples, and A. T. Adesogan. 2015a. Screening exogenous fibrolytic enzyme preparations for improved in vitro digestibility of bermudagrass haylage. J. Dairy Sci. 98:2555-2567. https://doi.org/10.3168/jds.2014-8059.

Rouches, E., I. Herpoël-Gimbert, J. P. Steyer, and H. Carrere. 2016. Improvement of anaerobic degradation by white-rot fungi pretreatment of lignocellulosic biomass: A review. Renew. Sustain. Energy Rev. 59:179-198. https://doi.org/10.1016/j.rser.2015.12.317.

Rudall, P. 2007. Anatomy of Flowering Plants. 3rd ed. Cambridge University Press, New York, NY.

Saloheimo, M., M. Paloheimo, S. Hakola, J. Pere, B. Swanson, E. Nyyssönen, A. Bhatia, M. Ward, and M. Penttilä. 2002. Swollenin, a Trichoderma reesei protein with sequence similarity to the plant expansins, exhibits disruption activity on cellulosic materials. Eur. J. Biochem. 269:4202-4211. https://doi.org/10.1046/j.1432-1033 .2002.03095.x

Sanchez-Duarte, J. I., K. F. Kalscheur, A. D. Garcia, and F. E. Contreras-Govea. 2019. Short communication: Meta-analysis of dairy cows fed conventional sorghum or corn silages compared with brown mibrid sorghum silage. J. Dairy Sci. 102:419-425. (In press).

Sarnklong, C., J. W. Cone, W. Pellikaan, and W. H. Hendriks. 2010. Utilization of rice straw and different treatments to improve its feed value for ruminants: A review. Asian-australas. J. Anim. Sci. 23:680-692. https://doi.org/10.5713/ajas.2010.80619.

Sattler, S. E., D. L. Funnell-Harris, and J. F. Pedersen. 2010. Brown midrib mutations and their importance to the utilization of maize, sorghum, and pearl millet lignocellulosic tissues. Plant Sci. 178:229-238. https://doi.org/10.1016/j.plantsci.2010.01.001.

Schingoethe, D. J., G. A. Stegeman, and R. J. Treacher. 1999. Response of lactating dairy cows to a cellulase and xylanase enzyme mixture applied to forages at the time of feeding. J. Dairy Sci. 82:996-1003. https://doi.org/10.3168/jds.S0022-0302(99)75319-1.

Seki, Y., Y. Kikuchi, R. Yoshimoto, and K. Aburai. 2015. Promotion of crystalline cellulose degradation by expansins from Oryza sativa. Planta 241:83-93. https://doi.org/10.1007/s00425-014-2163-6. 
Sethuraman, A., D. E. Akin, and K. E. L. Eriksson. 1998. Plant-cellwall-degrading enzymes produced by the white-rot fungus Ceriporiopsis Subvermispora. Biotechnol. Appl. Biochem. 27:37-47. https://doi.org/10.1111/j.1470-8744.1998.tb01373.x.

Shah, M. M., T. A. Grover, and S. D. Aust. 1991. Metabolism of cyanide by Phanerochaete chrysosporium. Arch. Biochem. Biophys. 290:173-178. https://doi.org/10.1016/0003-9861(91)90604-H.

Shahzad, F., M. Abdullah, A. S. Chaudhry, J. A. Bhatti, M. A. Jabbar, F. Ahmed, T. Mehmood, M. Asim, S. Ahmed, Z. Kamran, I. Irshad, and M. N. Tahir. 2016. Effects of varying levels of fungal (Arachniotus sp.) treated wheat straw as an ingredient of total mixed ration on growth performance and nutrient digestibility in Nili Ravi buffalo calves. Asian-australas. J. Anim. Sci. 29:359-364. https://doi.org/10.5713/ajas.15.0429.

Shi, H. T., S. L. Li, Z. J. Cao, Y. J. Wang, G. M. Alugongo, and P. H. Doane. 2015. Effects of replacing wild rye, corn silage, or corn grain with CaO-treated corn stover and dried distillers grains with solubles in lactating cow diets on performance, digestibility, and profitability. J. Dairy Sci. 98:7183-7193. https://doi.org/10.3168/ jds.2014-9273.

Shreck, A. L., B. L. Nuttelman, J. L. Harding, W. A. Griffin, G. E. Erickson, T. J. Klopfenstein, and M. J. Cecava. 2015. Digestibility and performance of steers fed low-quality crop residues treated with calcium oxide to partially replace corn in distillers grains finishing diets. J. Anim. Sci. 93:661-671. https://doi.org/10.2527/ jas.2013-7194.

Shrivastava, B., K. K. Jain, A. Kalra, and R. C. Kuhad. 2014. Bioprocessing of wheat straw into nutritionally rich and digested cattle feed. Sci. Rep. 4:6360. https://doi.org/10.1038/srep06360.

Silveira, R. L., and M. S. Skaf. 2016. Molecular dynamics of the $B a-$ cillus subtilis expansin EXLX1: Interaction with substrates and structural basis of the lack of activity of mutants. Phys. Chem. Chem. Phys. 18:3510-3521. https://doi.org/10.1039/c5cp06674c.

Sindhu, R., P. Binod, and A. Pandey. 2016. Biological pretreatment of lignocellulosic biomass - An overview. Bioresour. Technol. 199:7682. https://doi.org/10.1016/j.biortech.2015.08.030.

Singh, G. P., and T. J. Klopfenstein. 1998. Relative effect of feeding urea supplemented and ammoniated wheat straw of different particle size on the passage rate, particle break down rate and digestibility in sheep. Indian J. Dairy Sci. 51:328-334.

Smith, J., K. Sones, D. Grace, S. MacMillan, S. Tarawali, and M. Herrero. 2013. Beyond milk, meat, and eggs: Role of livestock in food and nutrition security. Anim. Front. 3:6-13. https://doi.org/ 10.2527/af.2013-0002.

Smith, K. F., R. J. Simpson, R. N. Oram, K. F. Lowe, K. B. Kelly, P. M. Evans, and M. O. Humphreys. 1998. Seasonal variation in the herbage yield and nutritive value of perennial ryegrass (Lolium perenne L.) cultivars with high or normal herbage water-soluble carbohydrate concentrations grown in three contrasting Australian dairy environments. Aust. J. Exp. Agric. 38:821-830.

Srebotnik, E., K. Messner, and R. Foisner. 1988. Penetrability of white rot-degraded pine wood by the lignin peroxidase of Phanerochaete chrysosporium. Appl. Environ. Microbiol. 54:2608-2614.

Stone, W. C., L. E. Chase, T. R. Overton, and K. E. Nestor. 2012. Brown midrib corn silage fed during the peripartal period increased intake and resulted in a persistent increase in milk solids yield of Holstein cows. J. Dairy Sci. 95:6665-6676. https://doi.org/ 10.3168/jds.2012-5531.

Sun, R., J. M. Lawther, and W. B. Banks. 1995. Influence of alkaline pre-treatments on the cell wall components of wheat straw. Ind. Crops Prod. 4:127-145. https://doi.org/10.1016/0926 -6690(95)00025-8.

Sun, Y., and J. J. Cheng. 2005. Dilute acid pretreatment of rye straw and bermudagrass for ethanol production. Bioresour. Technol. 96:1599-1606. https://doi.org/10.1016/j.biortech.2004.12.022.

Sundstol, F. 1988. Straw and other fibrous by-products. Livest. Prod. Sci. 19:137-158. https://doi.org/10.1016/0301-6226(88)90088-7.

Sundstol, F., and E. M. Coxworth. 1984. Ammonia treatment. Pages 196-247 in Straw and Other Fibrous Feed. F. Sundstol and E. Owens, ed. Elsevier, Amsterdam, the Netherlands.
Tamasloukht, B., M. S. Wong Quai Lam, Y. Martinez, K. Tozo, O. Barbier, C. Jourda, A. Jauneau, G. Borderies, S. Balzergue, J. P. Renou, S. Huguet, J. P. Martinant, C. Tatout, C. Lapierre, Y. Barriere, D. Goffner, and M. Pichon. 2011. Characterization of a cinnamoyl-CoA reductase 1 (CCR1) mutant in maize: effects on lignification, fibre development, and global gene expression. J. Exp. Bot. 62:3837-3848.

Tao, L., L. X. Zhang, Y. Tu, N. F. Zhang, B. W. Si, T. Ma, and Q. Y. Diao. 2016. Improving the in situ ruminal degradability of maize stalk using fungal inoculants in dorper $\times$ thin-tailed han crossbred ewes. Small Rumin. Res. 144:119-125. https://doi.org/10.1016/j .smallrumres.2016.09.001.

Taylor, C. C., N. J. Ranjit, J. A. Mills, J. M. Neylon, and L. Kung Jr. 2002. The effect of treating whole-plant barley with Lactobacillus buchneri 40788 on silage fermentation, aerobic stability and nutritive value for dairy cows. J. Dairy Sci. 85:1793-1800.

Taylor, L. E., Z. Dai, S. R. Decker, R. Brunecky, W. S. Adney, S. Y. Ding, and M. E. Himmel. 2008. Heterologous expression of glycosyl hydrolases in planta: A new departure for biofuels. Trends Biotechnol. 26:413-424. https://doi.org/10.1016/j.tibtech.2008.05 .002 .

Terashima, N., and K. Fukushima. 1993. Comprehensive model of lignified plant cell Wall. Forage Cell Wall Structure and Digestibility. Pages $247-270$ in Forage Cell Wall Structure and Digestibility. H. G. Jung, D. R. Buxton, R. D. Hatfield, and J. Ralph, ed. ASA, CSSA, and SSSA, Madison, WI.

Tirado-Gonzalez, D. N., L. A. Miranda-Romero, A. Ruiz-Flores, S. E. Medina-Cuellar, R. Ramirez-Valverde, and G. Tirado-Estrada. 2018. Meta-analysis: Effects of exogenous fibrolytic enzymes in ruminant diets. J. Appl. Anim. Res. 46:771-783. https://doi.org/ 10.1080/09712119.2017.1399135.

Torget, R., P. Walter, M. Himmel, and K. Grohmann. 1991. Diluteacid pretreatment of corn residues and short-rotation woody crops. Appl. Biochem. Biotechnol. 28/29:75-86. https://doi.org/10.1007/ bf02922590.

Torget, R., P. Werdene, M. Himmel, and K. Grohmann. 1990. Dilute acid pretreatment of short rotation woody and herbaceous crops. Appl. Biochem. Biotechnol. 24/25:115-126. https://doi.org/10 $.1007 /$ bf02920238.

Tuyen, V. D., J. W. Cone, J. J. P. Baars, A. S. M. Sonnenberg, and W. H. Hendriks. 2012. Fungal strain and incubation period affect chemical composition and nutrient availability of wheat straw for rumen fermentation. Bioresour. Technol. 111:336-342. https://doi .org/10.1016/j.biortech.2012.02.001.

USDA-NASS (National Agricultural Statistics Service). 2017. Crop production summary. https://quickstats.nass.usda.gov/.

Van Amburgh, M. E., E. A. Collao-Saenz, R. J. Higgs, D. A. Ross, E. B. Recktenwald, E. Raffrenato, L. E. Chase, T. R. Overton, J. K. Mills, and A. Foskolos. 2015. The Cornell net carbohydrate and protein system: Updates to the model and evaluation of version 6.5. J. Dairy Sci. 98:6361-6380. https://doi.org/10.3168/jds.2015 $-9378$.

van Kuijk, S. J. A., A. S. M. Sonnenberg, J. J. P. Baars, W. H. Hendriks, and J. W. Cone. 2015. Fungal treated lignocellulosic biomass as ruminant feed ingredient: A review. Biotechnol. Adv. 33:191-202. https://doi.org/10.1016/j.biotechadv.2014.10.014.

Van Soest, P. J. 1987. Effect of environment and quality of fibre on the nutritive value of crop residues. International Livestock Centre for Africa, Addis Adaba, Ethiopia.

Van Soest, P. J., M. E. Van Amburgh, J. B. Robertson, and W. F. Knaus. 2005. Validation of the 2.4 times lignin factor for ultimate extent of NDF digestion, and curve peeling rate of fermentation curves into pools. Pages 139-149 in Proc. Cornell Nutr. Conf. Feed Manuf., East Syracuse, NY.

Vanderwerff, L. M., L. F. Ferraretto, and R. D. Shaver. 2015. Brown midrib corn shredlage in diets for high-producing dairy cows. J. Dairy Sci. 98:5642-5652.

Verain, M. C. D., H. Dagevos, and G. Antonides. 2015. Sustainable food consumption. Product choice or curtailment? Appetite 91:375-384. 
Vismeh, R., D. Haddad, J. Moore, C. Nielson, B. Bals, T. Campbell, A. Julian, F. Teymouri, A. D. Jones, and V. Bringi. 2018. Exposure assessment of acetamide in milk, beef, and coffee using xanthydrol dericatization and gas chromatography/mass spectrometry. J. Agric. Food Chem. 66:298-305.

Vogel, J. 2008. Unique aspects of the grass cell wall. Curr. Opin. Plant Biol. 11:301-307. https://doi.org/10.1016/j.pbi.2008.03.002.

Vrsanska, M., S. Voberkova, V. Langer, D. Palovcikova, A. Moulick, V. Adam, and P. Kopel. 2016. Induction of laccase, lignin peroxidase and manganese peroxidase activities in white-rot fungi using copper complexes. Molecules 21:1553. https://doi.org/10.3390/ molecules21111553.

Wanapat, M., S. Kang, N. Hankla, and K. Phesatcha. 2013. Effect of rice straw treatment on feed intake, rumen fermentation and milk production in lactating dairy cows. Afr. J. Agric. Res. 8:16771687. https://doi.org/10.5897/AJAR2013.6732.

Wanapat, M., S. Polyorach, K. Boonnop, C. Mapato, and A. Cherdthong. 2009. Effects of treating rice straw with urea or urea and calcium hydroxide upon intake, digestibility, rumen fermentation and milk yield of dairy cows. Livest. Sci. 125:238-243. https: /doi.org/10.1016/j.livsci.2009.05.001.

Wang, W., C. Liu, Y. Ma, X. Liu, K. Zhang, and M. Zhang. 2014. Improved production of two expansin-like proteins in Pichia pastoris and investigation of their functional properties. Biochem. Eng. J. 84:16-27. https://doi.org/10.1016/j.bej.2013.12.018.

Wang, Y., T. A. McAllister, L. M. Rode, K. A. Beauchemin, D. P. Morgavi, V. L. Nsereko, A. D. Iwaasa, and W. Yang. 2001. Effects of an exogenous enzyme preparation on microbial protein synthesis, enzyme activity and attachment to feed in the rumen simulation technique (Rusitec). Br. J. Nutr. 85:325-332. https:// doi.org/10.1079/BJN2000277.

Weakley, D., D. R. Mertens, and M. McCaslin. 2008. Lactating cow responses to alfalfa hays with down-regulated lignin biosynthesis. J. Dairy Sci. 91(E-suppl 1):170. (Abstr.)

Weimer, P. J., Y. Chou, W. Weston, and D. Chase. 1986. Effect of supercritical ammonia on the physical and chemical structure of ground wood. Biotechnol. Bioeng. Symp. 17:5-18.

Weimer, P. J., J. M. Hackney, H.-J. G. Jung, and R. D. Hatfield. 2000. Fermentation of a bacterial cellulose/xylan composite by mixed ruminal microflora: Implications for the role of polysaccharide matrix interactions in plant cell wall biodegradability. J. Agric. Food Chem. 48:1727-1733. https://doi.org/10.1021/jf991372y.

Weimer, P. J., J. M. Lopez-Guisa, and A. D. French. 1990. Effect of cellulose fine structure on kinetics of its digestion by mixed ruminal microorganisms in vitro. Appl. Environ. Microbiol. 56:2421-2429.

Weimer, P. J., D. R. Mertens, E. Ponnampalam, B. F. Severin, and B. E. Dale. 2003. FIBEX-treated rice straw as a feed ingredient for lactating dairy cows. Anim. Feed Sci. Technol. 103:41-50. https:// doi.org/10.1016/S0377-8401(02)00282-1.
Wilson, J. R. 1993. Organization of forage plant tissues. Pages 1-32 in Forage Cell Wall Structure and Digestibility. H. G. Jung, D. R. Buxton, R. D. Hatfield, and J. Ralph, ed. ASA, CSSA, and SSSA, Madison, WI.

Wilson, J. R., and R. D. Hatfield. 1997. Structural and chemical changes of cell wall types during stem development: Consequences of fibre degradation by rumen microflora. Aust. Agric. Re. 48:165180. https://doi.org/10.1071/a96051.

Wilson, J. R., and P. M. Kennedy. 1996. Plant and animal constraints to voluntary feed intake associated with fiber characteristics and particle breakdown and passage in ruminants. Aust. J. Agric. Res. 47:199-225. https://doi.org/10.1071/ar9960199.

Wilson, J. R., and D. R. Mertens. 1995. Cell wall accessibility and cell structure limitations to microbial digestion of forage. Crop Sci. $35: 251-259$.

Wong, D. W. S. 2009. Structure and action mechanism of ligninolytic enzymes. Appl. Biochem. Biotechnol. 157:174-209. https://doi .org/10.1007/s12010-008-8279-z.

Wrathall, J. H. M., E. Owen, and D. J. Pike. 1989. Upgrading barley straw for goats: The effectiveness of a sodium hydroxide and urea dip method. Anim. Feed Sci. Technol. 24:57-67.

Yari, M., R. Valizadeh, A. A. Naserian, A. Jonker, A. Azarfar, and P. Yu. 2014. Effects of including alfalfa hay cut in the afternoon or morning at three stages of maturity in high concentrate rations on dairy cows performance, diet digestibility and feeding behavior. Anim. Feed Sci. Technol. 192:62-72.

Yelle, D. J., D. Wei, J. Ralph, and K. E. Hammel. 2011. Multidimensional NMR analysis reveals truncated lignin structures in wood decayed by the brown rot basidiomycete Postia placenta. Environ. Microbiol. 13:1091-1100. https://doi.org/10.1111/j.1462-2920 .2010.02417.x.

Yingjie, S., Y. Xiaoxiao, S. Yang, W. Gang, C. Huan, and C. Guang. 2018. Evaluation of screened lignin-degrading fungi for the biological pretreatment of corn stover. Sci. Rep. 8:5385. https://doi.org/ 10.1038/s41598-018-23626-6.

Yoon, S., S. P. Devaiah, S. E. Choi, J. Bray, R. Love, J. Lane, C. Drees, J. H. Howard, and E. E. Hood. 2016. Over-expression of the cucumber expansin gene (Cs-EXPA1) in transgenic maize seed for cellulose deconstruction. Transgenic Res. 25:173-186. https://doi .org/10.1007/s11248-015-9925-1.

Zhao, S., G. Li, N. Zheng, J. Wang, and Z. Yu. 2018. Steam explosion enhances digestibility and fermentation of corn stover by facilitating ruminal microbial colonization. Bioresour. Technol. 253:244251. https://doi.org/10.1016/j.biortech.2018.01.024.

Ziegelhoffer, T., J. Will, and S. Austin-Phillips. 1999. Expression of bacterial cellulase genes in transgenic alfalfa (Medicago sativa L.), potato (Solanum tuberosum L.) and tobacco (Nicotiana tabacum L.). Mol. Breed. 5:309-318. https://doi.org/10.1023/A: 1009646830403. 


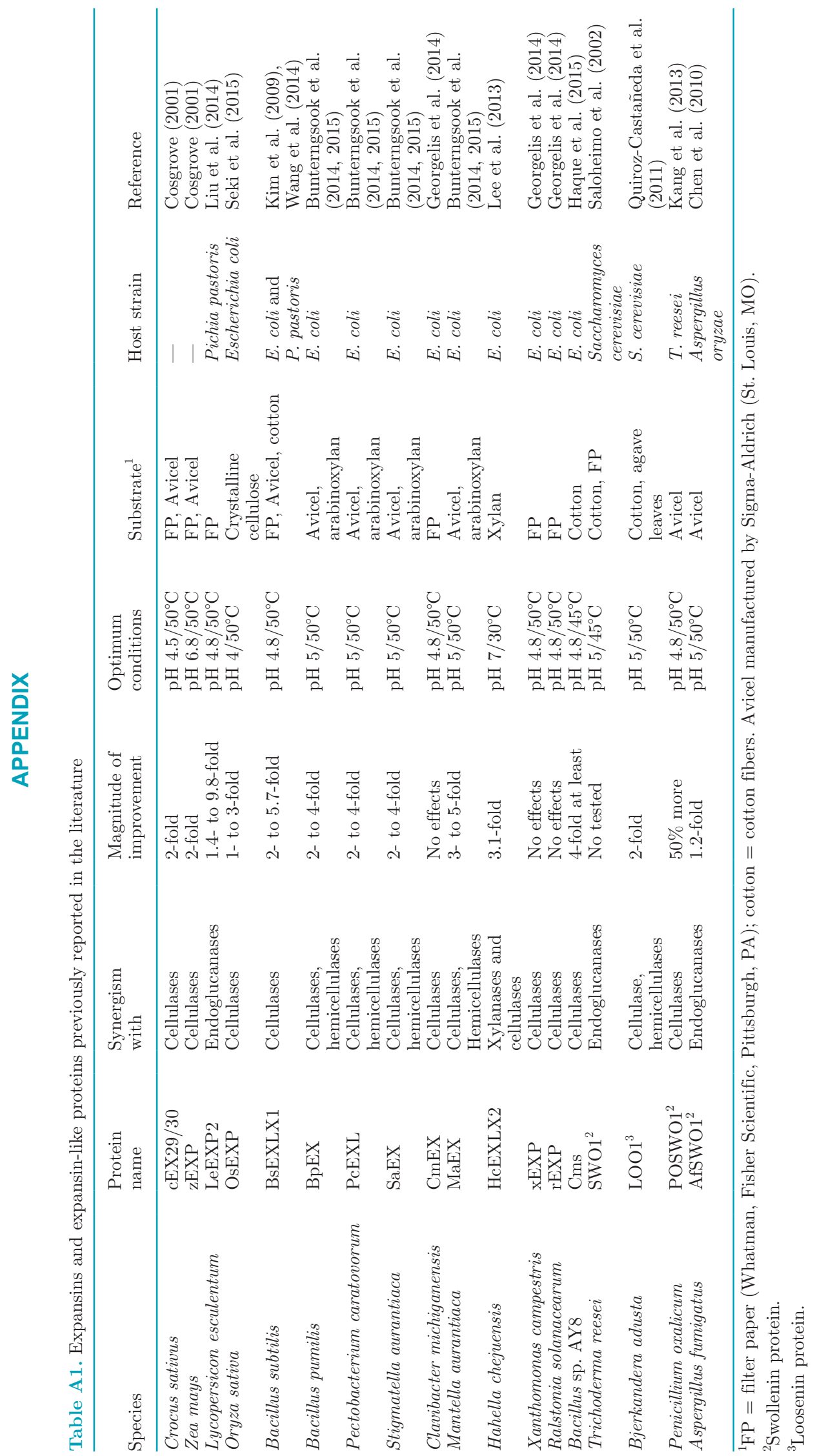

